\title{
Sustainability Supply Chain Management Research
}

\author{
A Structured Literature Review
}

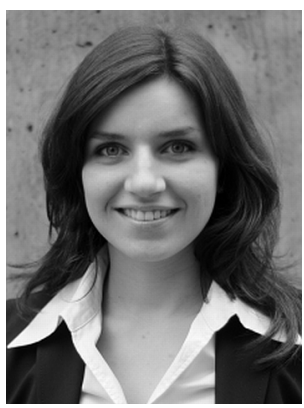

Nicole Kudla and Wolfgang Stölzle

Nachhaltigkeit, Corporate Social Responsibility, Supply Chain Management, Literaturanalyse

Sustainability, corporate social responsibility, supply chain management, literature review

Nachhaltigkeit verstanden als Gleichgewicht ökonomischer, ökologischer und sozialer Ziele nimmt nicht nur einen zentralen Stellenwert im Rahmen strategischer Unternehmensentscheidungen ein, sondern

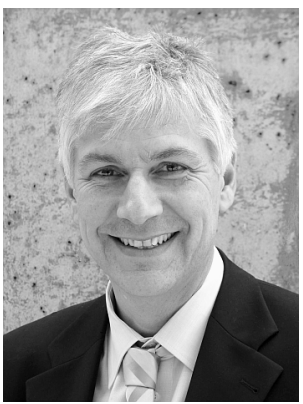
wird mehr und mehr als Weg „from good to great" verstanden. Berücksichtigt man die wachsende Bedeutung von Outsourcing-Aktivitäten sowie einer häufig komplexen und heterogenen Fremdfertigung, ist eine nachhaltige Ausrichtung nicht nur an die Unternehmens-, sondern unweigerlich an die Supply Chain-Ebene geknüpft. Das Zusammenwachsen dieser beiden noch relativ jungen Managementkonzepte wurde bislang kaum in der Forschung berücksichtigt. Zudem stellt sich das Forschungsumfeld stark fragmentiert dar, da sich unterschiedlichste Forschungsrichtungen mit "Sustainability SCM“ auseinandersetzen. Diese Arbeit hat das Ziel das Forschungsfeld „Sustainability SCM“ zu strukturieren. Dazu werden 223 Artikel aus 60 international relevanten Zeitschriften der Jahre 1987-2010 analysiert. Die Literaturanalyse umfasst sowohl deskriptive Charakteristika, wie die zeitliche und methodische Entwicklung des Forschungsfeldes, als auch die inhaltliche Entwicklung. In diesem Zusammenhang wird der Fokus bisheriger Nachhaltigkeitsuntersuchungen analysiert, Forschungslücken aufgezeigt und Handlungsempfehlungen für zukünftige Forschungsarbeiten abgeleitet.

Sustainability, implying the balance of economic, ecologic and social objectives, has not only made its way onto managers' agendas but is nowadays dealt with as the way "from good to great". Due to the superior role of outsourcing activities and complex as well as heterogeneous labor division, being sustainable demands not only a corporate, but a supply chain perspective. This convergence of two relatively young management concepts has rarely been contemplated in research yet. Moreover, research in the field is strongly fragmented to different research currents. In this context this article aims at an in-depth analysis of the research field by a structured literature review encompassing 223 papers out of 60 journals from 1987 until 2010. The review comprises an analysis of descriptive characteristics such as the development over time and methodologies. Furthermore, it copes with the point of view of sustainability research and identifies relevant research topics in order to derive implications for future research. 


\section{Introduction}

Sustainability is predicted as being one of the biggest opportunities in the history of commerce over the next decades. And it seems as if the forecasts become reality: whereas companies in the 1990s traditionally focused only on complying with national regulations in order to ensure that their business practices are judged as being acceptable and companies acted resistant towards environmental or social regulations (Walton et al.1998) - nowadays, multinational enterprises proactively establish sustainability or corporate social responsibility (CSR) initiatives, which affect more and more all actors within the supply chain network. This development underlines that the two management concepts of sustainability and supply chain management (SCM) are getting closer, not only in theory, but also in practice. Contemplating the developments of sustainability and SCM, it becomes obvious, that the increase of relevancy took place simultaneously for both topics since the late 1980s. Whereas SCM goes back on the schools of thought of chain awareness and logistics (Bechtel/Jayaram 1997; Giunipero et al. 2008), sustainability's origin bases on the often quoted definition of the Brundtland Commission, which defined sustainable development as “(...) development that meets the needs of the present without compromising the ability of future generations to meet their needs." (WCED 1987). This definition was extended later to the common concept of the triple bottom line, which balances the economic, environmental and social dimension (Elkington 1997).

Therefore, the first driver of this structured literature review is to identify relevant research currents in converging sustainability and SCM. The second driver became clear, when we began dealing with publications on sustainability: unclear definition and a variety of interpretations. Sustainability is often used in the same way as corporate responsibility ( Wu/ Dunn 1995; Bansal/Roth 2000; Waddock 2009) or sustainable development (Lélé 1991; Taylor 1994; Shrivastava 1995; Starik/Rands 1995; Gudmundsson/Höjer 1996; Wilson 2003; Endress et al. 2005). McWilliams et al. (2006, 10) also underlined the discrepancies of definitions by: "CSR has been used as a synonym for business ethics, defined as tantamount to corporate philanthropy, and considered strictly as relating to environmental policy. CSR has also been confused with corporate social performance and corporate citizenship." According to the growing interest on the topic in practice and theory, the objective of the review is to give a comprehensive overview and derive implications for future research on sustainability supply chain management (SSCM).

The academic implications of this review may be extracted from a closer look on existing reviews, their applied methodology, scope and major results. Table 1 presents selected analyzed publications, which clearly pointed out a structured review process, including a time frame, keywords as well as limitations of scope. Lockett et al. (2006) conducted a comprehensive literature analysis on corporate social responsibility. Their research covered publications in general management and several practitioner journals. They categorized the dimensions of CSR and found a strong focus on environmental as well as social issues. Furthermore, they figured out that citations within the analyzed articles did rarely reference across research currents. So that general management publications where cited mostly, followed by CSR and psychological articles. The analysis of the methodological background of the publications showed that the majority of CSR literature was of quantitative or nonnormative theoretical nature. Nonetheless, the review lacks deeper insights regarding to the development of contents in the field. Moreover, the authors contemplated an intraorganizational perspective, since they dealt with CSR. 


\begin{tabular}{|c|c|c|c|}
\hline Author (Year) & Methodology & Scope of Review & Major Results \\
\hline $\begin{array}{l}\text { Lockett, Moon } \\
\text { and Visser } \\
(2006)\end{array}$ & $\begin{array}{l}\text { Keywords: social, environ- } \\
\text { mental, ethics, stakehold- } \\
\text { ers } \\
\text { - Limitations: title and ab- } \\
\text { stract check to ensure CSR } \\
\text { relevancy } \\
\text { - Classification of CSR di- } \\
\text { mensions } \\
\text { - Classification of methodol- } \\
\text { ogy } \\
\text { - Influence check of } 8 \text { re- } \\
\text { search currents by analysis } \\
\text { of citations }\end{array}$ & $\begin{array}{l}\text { - } 176 \text { articles } \\
10 \text { manage- } \\
\text { ment jour- } \\
\text { nals ( } 7 \text { aca- } \\
\text { demic, } 3 \\
\text { practitioner) } \\
\text { - } 1992-2002\end{array}$ & $\begin{array}{l}\text { Majority of publications } \\
\text { has an environmental or } \\
\text { ethical focus } \\
\text { - Persistence of non-norma- } \\
\text { tive theoretical and quan- } \\
\text { titative empirical publica- } \\
\text { tions } \\
\text { - Dominating general man- } \\
\text { agement influence, fol- } \\
\text { lowed by CSR and psy- } \\
\text { chology journals }\end{array}$ \\
\hline $\begin{array}{l}\text { Srivastava } \\
(2007)\end{array}$ & $\begin{array}{l}\text { Keywords: green SC, green } \\
\text { Purchasing, green design, } \\
\text { industrial ecology, indus- } \\
\text { trial ecosystems, reverse lo- } \\
\text { gistics, remanufacturing, } \\
\text { waste management } \\
\text { - Limitations: firm-level op- } \\
\text { erational issues, highly } \\
\text { technical work } \\
\text { - No further specification of } \\
\text { the review process }\end{array}$ & $\begin{array}{l}1500 \text { books, } \\
\text { edited vol- } \\
\text { umes, jour- } \\
\text { nal articles } \\
\text { ( } 227 \text { cited) } \\
\text { - } 1990-2005 \\
\text { - Standard lit- } \\
\text { erature } \\
\text { databases } \\
\text { used }\end{array}$ & $\begin{array}{l}\text { Categorization / frame- } \\
\text { work for green SCM } \\
\text { - Evolutionary timeline } \\
\text { green SCM focusing on } \\
\text { green design, green oper- } \\
\text { ations and importance of } \\
\text { green SCM }\end{array}$ \\
\hline $\begin{array}{l}\text { Seuring/Müller } \\
\text { (2008b) }\end{array}$ & $\begin{array}{l}\text { Keywords: No keywords } \\
\text { specified } \\
\text { - Limitations: public pur- } \\
\text { chasing, ethical demands, } \\
\text { reverse logistics, remanu- } \\
\text { facturing } \\
\text { - First quick content check } \\
\text { for exclusion } \\
\text { - } 2 \text { researchers } \\
\text { - Check of citations } \\
\text { - Classification of sustain- } \\
\text { ability dimensions } \\
\text { - Classification of methodol- } \\
\text { ogy }\end{array}$ & $\begin{array}{l}\text { - } 191 \text { Papers } \\
\text { Peer-re- } \\
\text { viewed jour- } \\
\text { nals with } \\
\text { management } \\
\text { focus } \\
\text { - 1994-2007 } \\
\text { - Standard lit- } \\
\text { erature } \\
\text { databases } \\
\text { used }\end{array}$ & $\begin{array}{l}\text { Majority of publications } \\
\text { has an environmental fo- } \\
\text { cus } \\
\text { - Majority of publications } \\
\text { uses case-studies or sur- } \\
\text { veys } \\
\text { - Unspecified decision for } \\
\text { framework for SSCM } \\
\text { based on triggers, supplier } \\
\text { management for risk and } \\
\text { performance, SCM for } \\
\text { sustainable products }\end{array}$ \\
\hline
\end{tabular}

Table 1: Methodology, Scope and Major Results of previous Literature Reviews

Srivastava (2007) on the other hand focused on the supply chain, but on one dimension of sustainability only. He analyzed the development of green SCM. In this context he reviewed about 1,500 books, edited volumes and articles published between 1990 and 2005. As a 
result he built a comprehensive framework for green SCM and mapped the evolutionary timeline.

Seuring/Müller (2008b) were the only authors, who contemplated SSCM. Their review encompassed 191 papers published between 1994 and 2007. These were analyzed with respect to their main dimension and applied methodology. In contrast to Lockett et al. (2006), Seuring and Müller identified the environmental dimension as being the strongest, whereas the methodological analysis leads to similar results regarding to empirical and theoretical work in the field. The delimitation of their review is that they also did not specify the developments of contents in the field, but discuss triggers of sustainable SCM, supplier management and sustainable products as parts of the framework for SSCM randomly.

In comparison to previous literature reviews and the presented articles, this literature review fills the gap of a comprehensive and structured analysis on SSCM research. Firstly, it applies a documented and reconstructable research process, so that readers can "(...) assess the exhaustiveness of the review and other scholars in the field can more confidently (re)use the results in their own research." (vom Brocke et al. 2009, 1). Secondly, the comprehensive SSCM review focuses not on one dimension of sustainability only and contrasts intra- and interorganizational sustainability literature. Thirdly, it identifies relevant research topics and derives future research options.

\section{Methodology}

Due to the fact that the review aims at structuring the research field and giving a comprehensive state of research a methodological mix of qualitative content analysis as well as quantitative analysis methods is applied. The methodological frame follows Mayring's process model of content analysis, which comprises the process steps of data collection, descriptive analysis, category selection and material evaluation (Mayring 2003). These steps follow and summarize methodological processes and questions of conducting a structured literature review by the means of qualitative content analysis (e.g. Hart 1998; Webster/Watson 2002; Zikmund 2003; Atteslander 2006; vom Brocke et al. 2009).

\subsection{Data Collection}

The material collection process starts with a definition of the unit of analysis. Therefore, in a first step relevant research currents are defined as a basis for the review. Secondly, we select relevant journals from the identified research currents. Finally, the search criteria and time frame for the literature review are defined and justified.

In order to define relevant research currents for the literature search, we considered definitions and origins of sustainability and SCM. Corresponding to the triple bottom line concept, sustainability research is especially reflected by the research currents "general management", "environment" and "business ethics".

For SCM research, we base our selection of research currents on the comprehensive definition of Stock/Boyer (2009, 706): "The management of a network of relationships within a firm and between interdependent organizations and business units consisting of material suppliers, purchasing, production facilities, logistics, marketing, and related systems that facilitate the forward and reverse flow of materials, services, finances and information (...)" Hence, SCM as a management philosophy (Mentzer et al. 2001) also demands for "general 
management" as a research current. The intra- and interorganizational perspective demands for a consideration of "organization" research (e.g. Cooper et al. 1997). Beyond this, we contemplate the SCM relevant functionally-oriented research currents of "production", "logistics" and "marketing". Purchasing is not selected separately, since publications may predominantly be found in "production" and "logistics" journals.

The relevant journals for each research current are selected from the VHB-JOURQUAL 2 journal ranking by the German Academic Association for Business Research. Due to its up-to-date survey-based ranking of relevant journals in 24 research currents of business research a comprehensive overview of international journals is provided. From these 24 research currents: "general management", "organization", "production", "logistics", "marketing", "environment and business ethics" were chosen as being closest to the subject of the review. Table 2 gives an overview of the chosen top 10 journals in each research current. Since "production" and "logistics" have three overlapping journals, results are given for each current and duplicates are abstracted for totals.

\begin{tabular}{|c|c|c|c|}
\hline $\begin{array}{l}\text { Research } \\
\text { Current }\end{array}$ & Journal & $\begin{array}{l}\text { JOUR- } \\
\text { QUAL } 2 \\
\text { Ranking }\end{array}$ & $\begin{array}{c}\text { Number } \\
\text { of } \\
\text { Articles }\end{array}$ \\
\hline \multirow{10}{*}{$\begin{array}{l}\text { General } \\
\text { Manage- } \\
\text { ment } \\
(\mathrm{n}=46)\end{array}$} & Administrative Science Quarterly & $A+$ & 0 \\
\hline & Management Science & $A+$ & 1 \\
\hline & Academy of Management Journal & $A+$ & 3 \\
\hline & Academy of Management Review & $A+$ & 13 \\
\hline & Strategic Management Journal & A & 9 \\
\hline & Journal of Industrial Economics & A & 0 \\
\hline & Journal of Economics and Management Strategy & A & 10 \\
\hline & Organization Studies & $\mathrm{B}$ & 2 \\
\hline & Journal of Management & $\mathrm{B}$ & 1 \\
\hline & Journal of Management Studies & $\mathrm{B}$ & 7 \\
\hline \multirow{11}{*}{$\begin{array}{l}\text { Orga- } \\
\text { nization } \\
(\mathrm{n}=15)\end{array}$} & Organization Science & A & 1 \\
\hline & Journal of International Business Studies JIBS & A & 6 \\
\hline & Journal of Labor Economics & A & 0 \\
\hline & Journal of Applied Psychology & A & 0 \\
\hline & Journal of Economic Behavior and Organization & A & 1 \\
\hline & Organizational Behavior and Human Decision Processes & A & 0 \\
\hline & Journal of Law, Economics, and Organization & $\mathrm{B}$ & 0 \\
\hline & Research in the Sociology of Organizations & $\mathrm{B}$ & 0 \\
\hline & Journal of Strategic Information Systems & B & 3 \\
\hline & $\begin{array}{l}\text { Organizational Behaviour and Human Performance } \\
\text { (until 1984) }\end{array}$ & $B$ & \\
\hline & Human Relations & $\mathrm{B}$ & 4 \\
\hline
\end{tabular}




\begin{tabular}{|c|c|c|c|}
\hline $\begin{array}{l}\text { Research } \\
\text { Current }\end{array}$ & Journal & $\begin{array}{l}\text { JOUR- } \\
\text { QUAL } 2 \\
\text { Ranking }\end{array}$ & $\begin{array}{c}\text { Number } \\
\text { of } \\
\text { Articles }\end{array}$ \\
\hline \multirow{10}{*}{$\begin{array}{l}\text { Produc- } \\
\text { tion } \\
(\mathrm{n}=62)\end{array}$} & MIS Quarterly & A & 2 \\
\hline & Production and Operations Management & A & 5 \\
\hline & Discrete Applied Mathematics (see Logistics) & $A$ & 0 \\
\hline & IIE Transactions & A & 0 \\
\hline & Journal of Operations Management & $\mathrm{B}$ & 5 \\
\hline & Manufacturing and Service Operations Management & B & 0 \\
\hline & International Journal of Production Economics & $\mathrm{B}$ & 13 \\
\hline & International Journal of Production Research & $\mathrm{B}$ & 17 \\
\hline & Journal of Supply Chain Management (see Logistics) & $B$ & 10 \\
\hline & $\begin{array}{l}\text { International Journal of Physical Distribution and Lo- } \\
\text { gistics Management (see Logistics) }\end{array}$ & $B$ & 10 \\
\hline \multirow{10}{*}{$\begin{array}{l}\text { Logistics } \\
(\mathrm{n}=35)\end{array}$} & Transportation Science & A & 0 \\
\hline & Discrete Applied Mathematics & A & 0 \\
\hline & Naval Research Logistics & B & 0 \\
\hline & Transportation Research Part B: Methodological & B & 0 \\
\hline & Journal of Business Logistics & B & 3 \\
\hline & Journal of Supply Chain Management & $\mathrm{B}$ & 10 \\
\hline & $\begin{array}{l}\text { International Journal of Physical Distribution and Lo- } \\
\text { gistics Management }\end{array}$ & $\mathrm{B}$ & 10 \\
\hline & Transportation Research Part A:Policy and Practice & $\mathrm{B}$ & 4 \\
\hline & $\begin{array}{l}\text { Transportation Research Part E: Logistics and Trans- } \\
\text { portation Review }\end{array}$ & $\mathrm{B}$ & 5 \\
\hline & $\begin{array}{l}\text { International Journal of Logistics; Research and Appli- } \\
\text { cations }\end{array}$ & $\mathrm{C}$ & 3 \\
\hline \multirow{10}{*}{$\begin{array}{l}\text { Marketing } \\
(\mathrm{n}=18)\end{array}$} & Journal of Marketing & $A+$ & 5 \\
\hline & Journal of Consumer Research & $A+$ & 0 \\
\hline & Journal of Marketing Research & $A+$ & 1 \\
\hline & Marketing Science & $A+$ & 0 \\
\hline & Journal of the Academy of Marketing Science & A & 6 \\
\hline & Journal of Service Research & A & 4 \\
\hline & Journal of Applied Psychology (see Organization) & $A$ & 0 \\
\hline & International Journal of Research in Marketing & A & 2 \\
\hline & Journal of Retailing & A & 0 \\
\hline & Journal of Product Innovation Management & A & 0 \\
\hline \multirow{10}{*}{$\begin{array}{l}\text { Environ- } \\
\text { ment / } \\
\text { Business } \\
\text { Ethics } \\
(\mathrm{n}=67)\end{array}$} & Journal of Industrial Ecology & A & 6 \\
\hline & Business Ethics Quarterly & $\mathrm{B}$ & 3 \\
\hline & Ecological Economics & $\mathrm{B}$ & 1 \\
\hline & Business Strategy and the Environment & $\mathrm{B}$ & 10 \\
\hline & Zeitschrift für Umweltpolitik und Umweltrecht & $\mathrm{B}$ & 0 \\
\hline & Journal of Business Ethics & $\mathrm{C}$ & 17 \\
\hline & Journal of Environmental Economics and Management & $\mathrm{C}$ & 0 \\
\hline & $\begin{array}{l}\text { International Journal of Innovation and Sustainable De- } \\
\text { velopment }\end{array}$ & $\mathrm{C}$ & 1 \\
\hline & Journal of Cleaner Production & $\mathrm{C}$ & 30 \\
\hline & Journal of Macromarketing & $\mathrm{C}$ & 0 \\
\hline
\end{tabular}

Table 2: Scope of the Literature Review: Research Currents, Journals, Ranking and Hits (Source: Schrader/Hennig-Thurau 2009) 
A broad contemplation of the research field demands for search criteria, which must not be strongly delimiting. Furthermore, the criteria should balance the fact that the research topic suffers from a variety of terms and unclear definitions. The SCM related research currents demand for search criteria, which elucidate the state-of-research of sustainability issues within SCM. As a result, "sustainability", "sustainable", "green" and "responsibility" are chosen as keywords.

"Sustainability" as well as "sustainable" lead partially to publications on sustainable competitive advantage or regional sustainable development. These publications are excluded from the sample. Due to the recent popularization of the term "green" encompassing environmental, but also sustainability strategies, this term is also included in the search. Publications on for instance the color "green" or other meanings are certainly excluded. Finally, the term "responsibility" is selected to find articles on CSR related papers. Although, "environment" and "ethics" seem to be adequate keywords as well, they are intentionally factored out, due to the diversity of meanings and interpretations.

The literature search in the "environment and business ethics" research current is conducted diametrical, so that the objective is to find out to what extent researchers are coping with SCM issues. Hence, "supply chain" and "SCM" are chosen as keywords.

The keyword search is conducted as a title-search for each journal using the common databases of EBSCO, Proquest, Science direct and Interscience Wiley. In case no access to the journal is available, the review is conducted "manually" by screening the table of contents of the journals for the relevant time frame. The exclusion of not related articles, mentioned above, is conducted in a second abstract review stage. Within this stage the number of articles was reduced from 342 to 223 . Due to the wide-spread usage of the keywords "sustainable" or "responsibility", an abstract-search leads to more than 1,600 hits. The title-search limits the number of results strongly, provides the basis for a reconstructable abstract review process and thus, for a structured literature review.

The time frame is intentionally selected to cover the main development phase of SSCM research. Therefore, the time range starts with the year of publication of the Brundtland report in 1987, which is known as the first approved definition on sustainability.

\subsection{Descriptive Analysis}

The descriptive analysis encompasses the formal parts of the review. Based on the thought of explication in order to gain deeper knowledge of the content, the material is categorized according to theory-driven and content-driven categories (e.g. Mayring 2002; Krippendorff 2004). In this review these formal parts cope with the questions:

1. What relevance have sustainability and SSCM research within the defined research currents of business research?

2. What type of methodology is applied within the article? Does the allocation of methodology types change over time?

The analysis regarding to the first question quantifies the identified literature basis. The second question classifies its methodology types. Therefore, qualitative and quantitative methodologies, namely literature reviews, conceptual or theoretical articles, case-studies, empirical analyses and models or mathematical approaches are distinguished. This categorization is validated by an iterative review process. As a result from the abstract review, each article is classified in one category only. In case the abstract did not allow a categorization, the methodological section of the articles is considered. For publications ap- 
plying methodology triangulation, the type from which the major results were concluded, is chosen.

\subsection{Category Selection and Material Evaluation}

According to conventional qualitative content analysis (Mayring 2003; Hsieh/Shannon $2005)$, the category selection and material evaluation process consists of an inductive selection of categories, a definition and coding for each category, an in-depth analysis of the material followed by the preparation of results as well as an iterative revision of the categories and the coding.

For the first classification, the fundamental definition of sustainability is applied: Elkington's concept of the triple bottom line. Despite the tripartite concept of sustainability, Lockett et al. (2006) and Seuring/Müller (2008) underlined that most publications focus on the environmental or societal point of view only. We want to contrast the stated one-dimension and the holistic point of view of sustainability. Therefore, we distinguish three categories: publications, which concentrate on the environmental or societal perspective only, and those which encompass all dimensions of sustainability. The economic dimension is not included as a separate point of view, due to its omnipresence in business research.

Most articles define their sustainability understanding or focus in the title, abstract or in a comprehensive definition at the beginning of their article. Therefore, the material evaluation and sorting regarding to the point of view is conducted predominantly within the abstract review stage.

3. What point of view is taken within the article: environmental, societal or sustainable?

Does the allocation change over time?

The second classification is of inductive nature, since it aims at an identification of major research topics within the field. In this context, the categories are found by material reduction through summarizing, which belongs to the group of reductive, qualitative content analysis techniques (e.g. Lamnek 2005). This technique contains a first explorative material review, which leads to a set of categories. These categories are iteratively generalized and defined until satisfying criteria for the analysis of research topics have been found.

4. Which research topic does the article deal with?

Does the allocation change over time?

Finally, the third classification qualifies the rather broad keyword search. Due to the choice of keywords, the publications are not necessarily in an interorganizational supply chain context. Hence, a categorization regarding to the intra- or interorganizational focus is required in order to analyze the degree of convergence of both concepts.

5. In which ratio are intra- versus interorganizational sustainability publications? Does the allocation change over time?

\section{Analysis of Sustainability Supply Chain Management Literature}

The discussion of results is structured according to the previously stated research questions. The first three sub-chapters deal with the descriptive analysis of the literature in scope, whereas the following parts cope with the material evaluation regarding to the selected categories on the sustainability point of view, the relevant research topics as well as the interand intraorganizational issues. 


\subsection{Relevancy of Sustainability and SSCM in Business Research}

The contemplation of the literature sample of 223 articles, according to search criteria, research currents and time, gives significant descriptive insights into the research field. Figure 1 shows the distribution of literature within the analyzed time range. It underlines that CSR and sustainability issues have increased in popularity and academic interest since the turn of the millennium significantly: $91 \%$ of all reviewed articles were published since 2000 and even $75 \%$ from 2005 onwards. The strong increase may also be explained by an increase of publications in total within the time range.

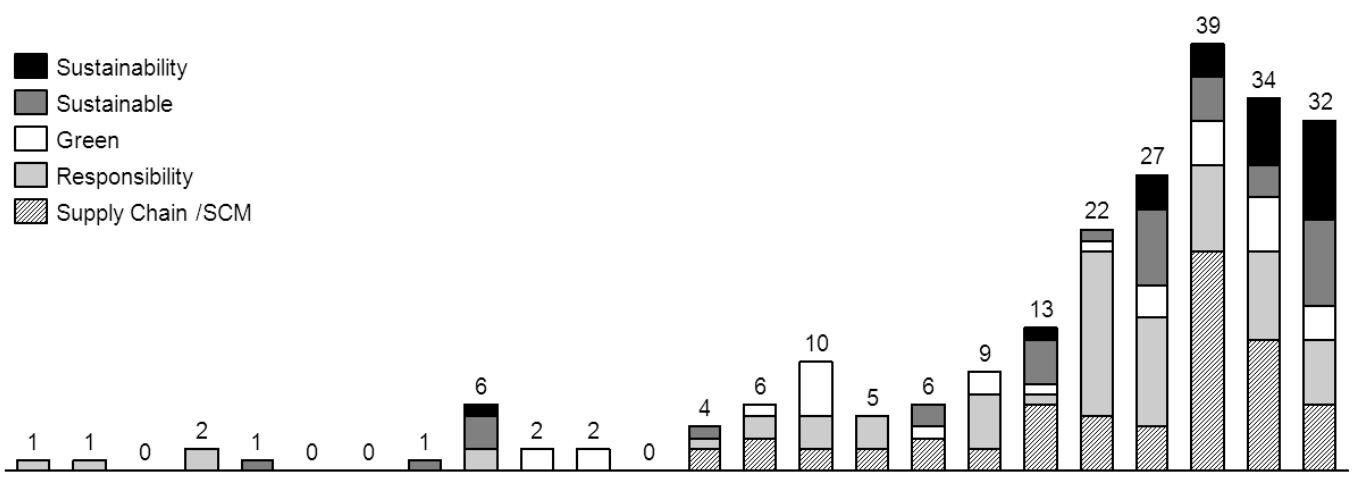

198719881989199019911992199319941995199619971998199920002001200220032004200520062007200820092010

Figure 1: Distribution of Literature according to Search Criteria

Beyond this, the escalations in 1995, 2001 and from 2006 onwards may be explained by numerous special issues on sustainability and CSR listed in Table 3.

\begin{tabular}{|c|c|c|c|}
\hline Journal Title & Year & Vol. / Iss. & Special Issue Title \\
\hline $\begin{array}{l}\text { Academy of Manage- } \\
\text { ment Review }\end{array}$ & 1995 & $\begin{array}{l}\text { Vol. } 20 / \\
\text { Iss. } 4\end{array}$ & Ecologically Sustainable Organizations \\
\hline $\begin{array}{l}\text { Production and Opera- } \\
\text { tions Management }\end{array}$ & 2001 & $\begin{array}{l}\text { Vol. } 10 / \\
\text { Iss. } 2,3\end{array}$ & Environmental Management and Operations \\
\hline $\begin{array}{l}\text { Journal of Manage- } \\
\text { ment Studies }\end{array}$ & 2006 & $\begin{array}{l}\text { Vol. } 43 \text { / } \\
\text { Iss. } 1\end{array}$ & $\begin{array}{l}\text { Corporate Social Responsibility: Strategic Impli- } \\
\text { cations }\end{array}$ \\
\hline $\begin{array}{l}\text { Journal of Internation- } \\
\text { al Business Studies }\end{array}$ & 2006 & $\begin{array}{l}\text { Vol. } 37 \text { / } \\
\text { Iss. } 6\end{array}$ & $\begin{array}{l}\text { Three Lenses on the Multinational Enterprise: } \\
\text { Politics, Corruption and Corporate Social Re- } \\
\text { sponsibility }\end{array}$ \\
\hline $\begin{array}{l}\text { International Journal } \\
\text { of Production Research }\end{array}$ & 2007 & $\begin{array}{l}\text { Vol. } 45 / \\
\text { Iss. } 18,19\end{array}$ & Sustainable Design and Manufacture \\
\hline $\begin{array}{l}\text { Journal of Operations } \\
\text { Management }\end{array}$ & 2007 & $\begin{array}{l}\text { Vol. } 25 / \\
\text { Iss. } 6\end{array}$ & $\begin{array}{l}\text { Supply Chain Management in a Sustainable En- } \\
\text { vironment }\end{array}$ \\
\hline $\begin{array}{l}\text { Journal of Cleaner Pro- } \\
\text { duction }\end{array}$ & 2008 & $\begin{array}{l}\text { Vol. } 16 / \\
\text { Iss. } 15\end{array}$ & Sustainability and Supply Chain Management \\
\hline
\end{tabular}




\begin{tabular}{|c|c|c|c|}
\hline Journal Title & Year & Vol. / Iss. & Special Issue Title \\
\hline $\begin{array}{l}\text { International Journal } \\
\text { of Production Eco- } \\
\text { nomics }\end{array}$ & 2008 & $\begin{array}{l}\text { Vol. } 111 / \\
\text { Iss. } 2\end{array}$ & Sustainable Supply Chain \\
\hline $\begin{array}{l}\text { Business Strategy and } \\
\text { the Environment }\end{array}$ & 2008 & $\begin{array}{l}\text { Vol. } 17 \text { / } \\
\text { Iss. } 7\end{array}$ & Strategic Sustainability Management \\
\hline $\begin{array}{l}\text { Journal of Business } \\
\text { Ethics }\end{array}$ & 2009 & $\begin{array}{l}\text { Vol. } 85 \text { / } \\
\text { Iss. } 2\end{array}$ & Corporate Social Responsibility Implementation \\
\hline $\begin{array}{l}\text { Journal of Supply } \\
\text { Chain Management }\end{array}$ & 2009 & $\begin{array}{l}\text { Vol. } 45 \text { / } \\
\text { Iss. } 4\end{array}$ & Sustainable Supply Chain Management \\
\hline $\begin{array}{l}\text { Journal of Economics } \\
\& \text { Management Strate- } \\
\text { gy }\end{array}$ & 2009 & $\begin{array}{l}\text { Vol. } 18 \text { / } \\
\text { Iss. } 1\end{array}$ & Management Strategy and the Environment \\
\hline $\begin{array}{l}\text { International Journal } \\
\text { of Physical Distribu- } \\
\text { tion \& Logistics Man- } \\
\text { agement }\end{array}$ & 2010 & $\begin{array}{l}\text { Vol. } 40 / \\
\text { Iss. } 1,2\end{array}$ & $\begin{array}{l}\text { The sustainable agenda and energy efficiency: } \\
\text { logistics solutions and supply chains in times of } \\
\text { climate change }\end{array}$ \\
\hline
\end{tabular}

Table 3: Overview of Special Issues within Journals of the Literature Sample

A closer look on the development of search criteria in the time range shows a paradigm change of terms. Since 2007 "sustainability" and "sustainable" are preferred in comparison to the term "responsibility".

Table 4 gives an overview of the results for each research current and the search criteria. The SCM-related research currents show significant differences for sustainability issues. "General management", "production" and "logistics" journals have published the majority of articles. It also becomes obvious, that the research currents seem to favor different terms. Whereas in "general management" $65 \%$ of the articles deal with corporate social "responsibility" issues, the "logistics" and "production" literature, favors the terms "sustainability" and "sustainable". The research currents "organization" and "marketing" account for only $10 \%$ and $12 \%$ of the total number of articles from SCM-related currents, with a majority of articles referring to "responsibility". The relatively low number of total articles may indicate a future research opportunity.

Within "environmental and business ethics" journals, 67 publications are found on supply chain topics. $79 \%$ of these articles are published after 2005 . The significant increase in 2008 is due to three special issues in this year within the research current.

\begin{tabular}{cccccc}
\hline Keyword & “Sustainability” & "Sustainable” & “Green” & "Responsibility” & Total \\
\hline $\begin{array}{c}\text { General } \\
\text { Management }\end{array}$ & 2 & 5 & 9 & 30 & 46 \\
\hline Organization & 3 & 2 & 1 & 9 & 15 \\
\hline Production & $15(8)$ & $22(15)$ & $15(14)$ & $10(5)$ & $62(42)$ \\
\hline Logistics & 8 & 11 & 6 & 10 & 35 \\
\hline
\end{tabular}




\begin{tabular}{cccccc}
\hline Keyword & "Sustainability" & "Sustainable" & "Green” & "Responsibility” & Total \\
\hline Marketing & 2 & 2 & 0 & 14 & 18 \\
\hline Total & $(23)$ & $(35)$ & $(30)$ & $(68)$ & $(156)$ \\
\hline Keyword & "Supply Chain" / "SCM" & & & Total \\
\hline $\begin{array}{c}\text { Environment / } \\
\text { Business } \\
\text { Ethics }\end{array}$ & 67 & & & 67 \\
\hline
\end{tabular}

Table 4: Results of Keyword Search within Research Currents (without duplicate journals)

\subsection{Use of Quantitative and Qualitative Research Methodologies}

When we want to contrive the researchers' perspective on a certain problem, the applied methodology gives indications on the presumable research goal and the issues dealt with. Mentzer (2008) refers to three main research objectives: maximization of generalizability of population contingents, maximization of precision and control regarding to the construct validity of concepts and maximization of the realism of context. These objectives can be achieved by different methods, which lead to the paradigm argument between quantitative and qualitative research, between explaining and understanding and between natural and social sciences (Lamnek 2005). Quantitative research aims at explaining a behavior or issue by models or empirical evident relations (Atteslander 2006). The fact of theory testing indicates that quantitative methods, such as surveys, observations or content analysis, are rather used in a more developed state of research. Guba/Lincoln $(1994,106)$ stated that "scientific maturity is commonly believed to emerge as the degree of quantification found within a given field increases".

The principles of qualitative research, on the other hand, are based on the objective of understanding. Mayring (2002) demanded in this context for a stronger subject-orientation of qualitative research, a stronger emphasis on description and interpretation as well as the consideration of the natural environment of the research subject. By the means of case studies, literature reviews or conceptual and theoretical approaches, qualitative research contributes to a deeper insight on understanding problems in the research field and is therefore appropriate to enter new fields of interest in research.

Within this analysis the occurrence and development of both quantitative and qualitative research methods is taken into account. Models and empirical analyses are distinguished in terms of quantitative research, whereas case studies, literature reviews and conceptual or theoretical approaches are found in qualitative research works. Figure 2 shows the results of this analysis. The above figure presents the total number of hits as well as the distribution across quantitative and qualitative research methods in four time clusters. It shows a decreasing dominance of qualitative research, which indicates the development of the field. Within the major time cluster 2005-2010 the methodology application is nearly equally distributed with $47 \%$ of quantitative and $53 \%$ of qualitative approaches.

For the major time cluster, we also analyzed whether research currents favor different research methodologies. The lower part of Figure 2 gives insights on the distribution. The width of the column indicates the number of hits per research current. It can be seen that quantitative methodology is applied in $55 \%$ to $64 \%$ of the publications in "general man- 


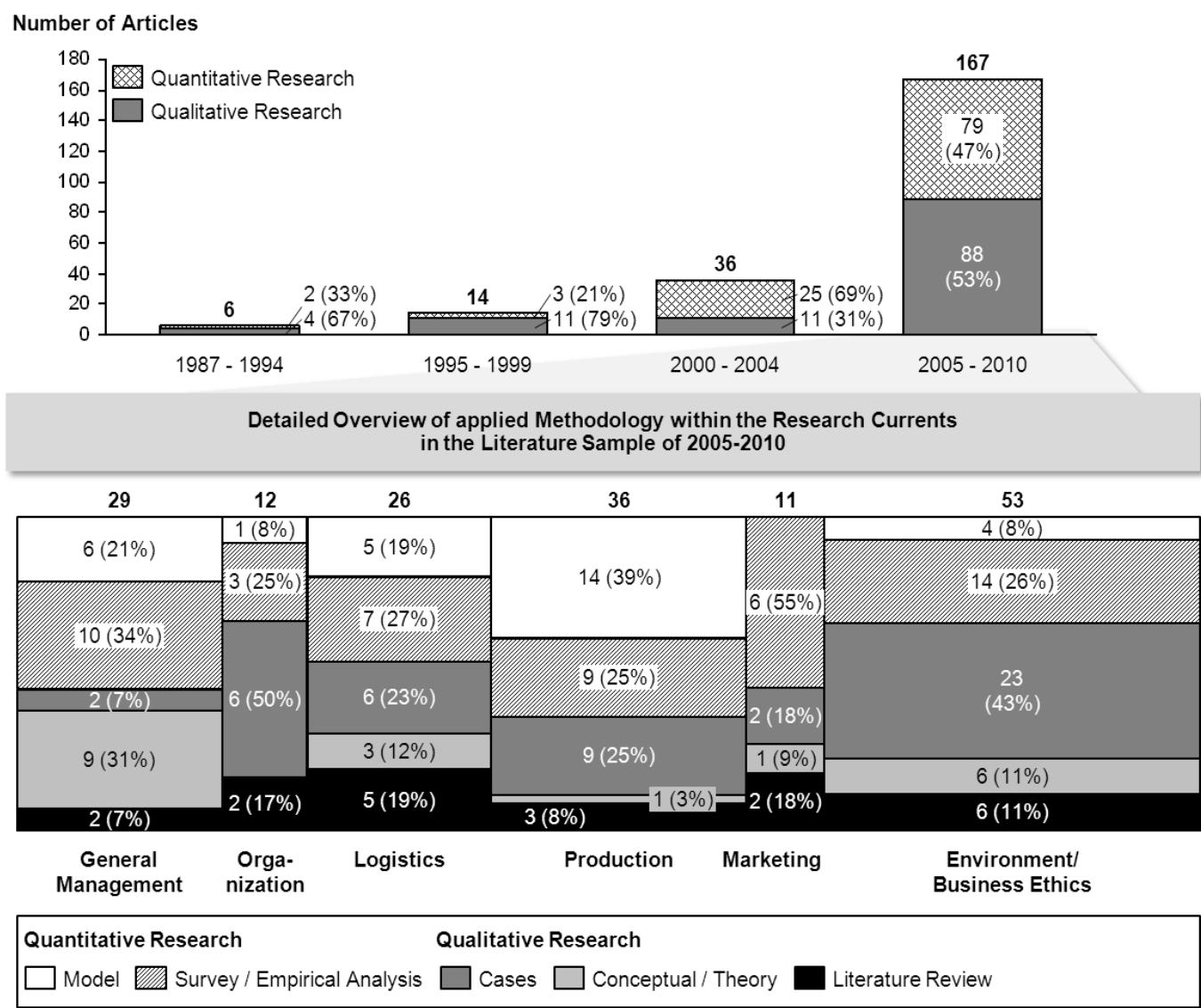

Figure 2: Analysis of Methodologies applied in the Literature Sample

agement", "production" and "marketing". In contrast quantitative research amounts to $34 \%$ within "environment and business ethics". This discrepancy in methodology application may be related to the different search criteria applied for SCM related research currents. Therefore, we conclude that CSR research has achieved a certain maturity already, whereas sustainability in an SCM context is still in its beginning. This fact may also explain the strong distribution difference between the time clusters 2000-2004 and 2005-2010.

Although the occurrence of modeling approaches increased in the past years, it can be seen that quantitative methods are dominated by empirical analyses. In qualitative research, on the other hand, case-studies are conducted in 54\% of all articles. Due to the vast majority of case study approaches, a closer look needs to be taken on their role within theory building and the development of SSCM. Case studies are particularly appropriate for addressing research questions, where knowledge of a business context is essential (Yin 2003). Mintzberg (2005) also highlighted that the method is suitable for addressing context-oriented and process-oriented research questions. The frequency of case study approaches in the sample underlines that research in SSCM is practice driven. That leads to the conclusion that SSCM demands for more research effort in theory building. 
At the beginning of this chapter, we pointed out, that the contemplation of applied methodology enables conclusions regarding to the research problem. This statement also needs to be considered vice versa. As we will see in the following part of the material evaluation with respect to categories, each research current obtains trends for certain kinds of research problems. "General management" and "marketing" for instance, have a strong interest on the influence of sustainability and CSR on firm performance, which makes the application of empirical analyses necessary and explains the frequency of this methodology type.

\subsection{Sustainability Point of View}

Research on sustainability suffers from unclear understanding and a variety of interpretations. These issues do not only become clear from the diversity of terms applied, but especially by the different point of views taken within research. The contemplation of the facets of the triple bottom line and the ongoing discussion about the integration of the economic, environmental and societal dimension leads to the fact, that researchers focus either on one of the dimensions or on sustainability, as a balance. An exclusive contemplation of the economic dimension, as for instance sustainable competitive advantage research was excluded from the sample due to its distinction from the triple bottom line understanding of sustainability

Dyllick/Hockerts (2002) went beyond the traditional framework and defined six criteria for corporate sustainability, namely eco-efficiency, eco-effectiveness, socio-efficiency, socioeffectiveness, sufficiency and ecological equity. Nonetheless, they acknowledged that despite of eco-efficiency, sufficient frameworks on the other criteria are still missing. Hence, the tripartite categorization in an environmental, societal and sustainable point of view seems most adequate in order to prevent incorrect classification. Each article was assigned to one of the three categories according to the following codes:

- Environmental: An environmental point of view is distinguished by its focus on ecological sustainability (e.g. Shrivastava 1995; Jennings/Zandbergen 1995) or green strategies (e.g. Murphy et al. 1996; Sheu et al. 2005; Sheu 2008; Zhu 2008). It copes with environmental issues, such as natural resource effectiveness and efficiency (e.g. Schliephake et al. 2009; Halldórsson/Kovács 2010; van Hoek/Johnson 2010), life-cycle-management (e.g. Seuring 2004a) and life-cycle-assessment, implying the determination of external effects (e.g. Tan/Khoo 2005; Matos/Hall 2007) but also green product development (e.g. Toolsema 2009) or environmental policies (e.g. Mintcheva 2005; Zhu/Sarkis 2007; Chen/Sheu 2009; Nawrocka et al. 2009)

- Societal: A societal or social point of view is classified according to the pyramid of social responsibility stated by Carroll (1991), who categorized the four dimensions: "Economic: Be profitable! (...) Legal: Obey the Rule! (...) Ethical: Obligation to do what is right" and "Philanthropic: Contribute resources to the community in order to improve the quality of live". In contrast to the environmental perspective, the societal point of view focuses on extra- or intraorganizational societal and social development, as for instance, social welfare implying healthcare or social security, but also education and employee development. Most publications in this context deal with standards, policies and code of conducts (e.g. Amaeshi et al. 2008; Kortelainen 2008; Jiang 2009) conflicts of multinational enterprises acting in different legal and ethical environments (e.g. Husted/Allen 2006; Strike 
et al. 2006; Cramer 2008; Krueger 2008) and in a supply chain context spoken: purchasing and social responsibility.

- Sustainable: The sustainable point of view is identified when an integration of the triple bottom line dimensions is apparent. This mostly occurred in the context of conceptual frameworks (e.g. Basu/Palazzo 2008; Carter/Rogers 2008; Matten/Moon 2008; Pagell/ Wu 2009), an opposing consideration of dimensions (e.g. Gladwin et al. 1995; Pullman et al. 2009) or with respect to operationalization (e.g. Bansal 2005; Koplin et al. 2007; Petrini/Pozzebon 2009).

Figure 3 shows the categorization results of the literature sample. Absolute figures of the literature sample elucidate that the environmental point of view accounts for $46 \%$ of the publications. In contrast, the societal and sustainable point of view amount for $20 \%$ and $36 \%$, respectively. This distribution can be explained by the historical dominance of the environmental point of view. Both the social dimension and sustainable development increased in relevance since 2000. Nonetheless, the distribution for 2005-2010 presents a significant increase for the sustainability point of view, whereas the societal perspective still amounts for $19 \%$. The lower part of Figure 3 presents a more differentiated picture. In "organization" and "marketing" the societal point of view is prevalent, whereas "production" and "environment and business ethics" are dominated by the green point of view. The largest numbers of comprehensive perspective publications can be found in the CSR literature in "general management" and in sustainability related publications in "logistics" journals.

As a conclusion, the research field still demands for theoretical frameworks, concrete definitions and operationalization approaches from a societal point of view. In the SCM and logistics community, for instance, this work is solely done by Carter and Jennings (Carter) Jennings 2002a; Carter/Jennings 2002b; Carter 2004; Carter/Jennings 2004; Carter 2005). Based on this work, comprehensive integration of all dimensions can take place in future research.

\subsection{Relevant Topics in Sustainability Supply Chain Management Research}

Finally, relevant topics in SSCM research shall be identified and presented in detail. As described in chapter 2.3, the topic categories were selected inductively and iteratively during the review process. This process started with a title and abstract review in order to select a topic category summarizing the content dealt with in the article. After the review of all articles from each research current, the different topics documented were clustered and aggregated. In a final step, the selected categories for all research currents were contemplated again and clustered to five main categories. A cluster was confirmed as satisfying when each article could be assigned to one cluster and no further summarization of clusters was reasonable. The restriction for the assignment of each article to only one category is helpful to evaluate the meaning and development of each category. Although, this categorization may not be distinct in all cases and depends on the researchers' perspective, it provides a pragmatic approach for a first literature analysis and supports structuring the field. For reconstruction purposes the assignment of all publication of the literature sample is given in the Appendix. 


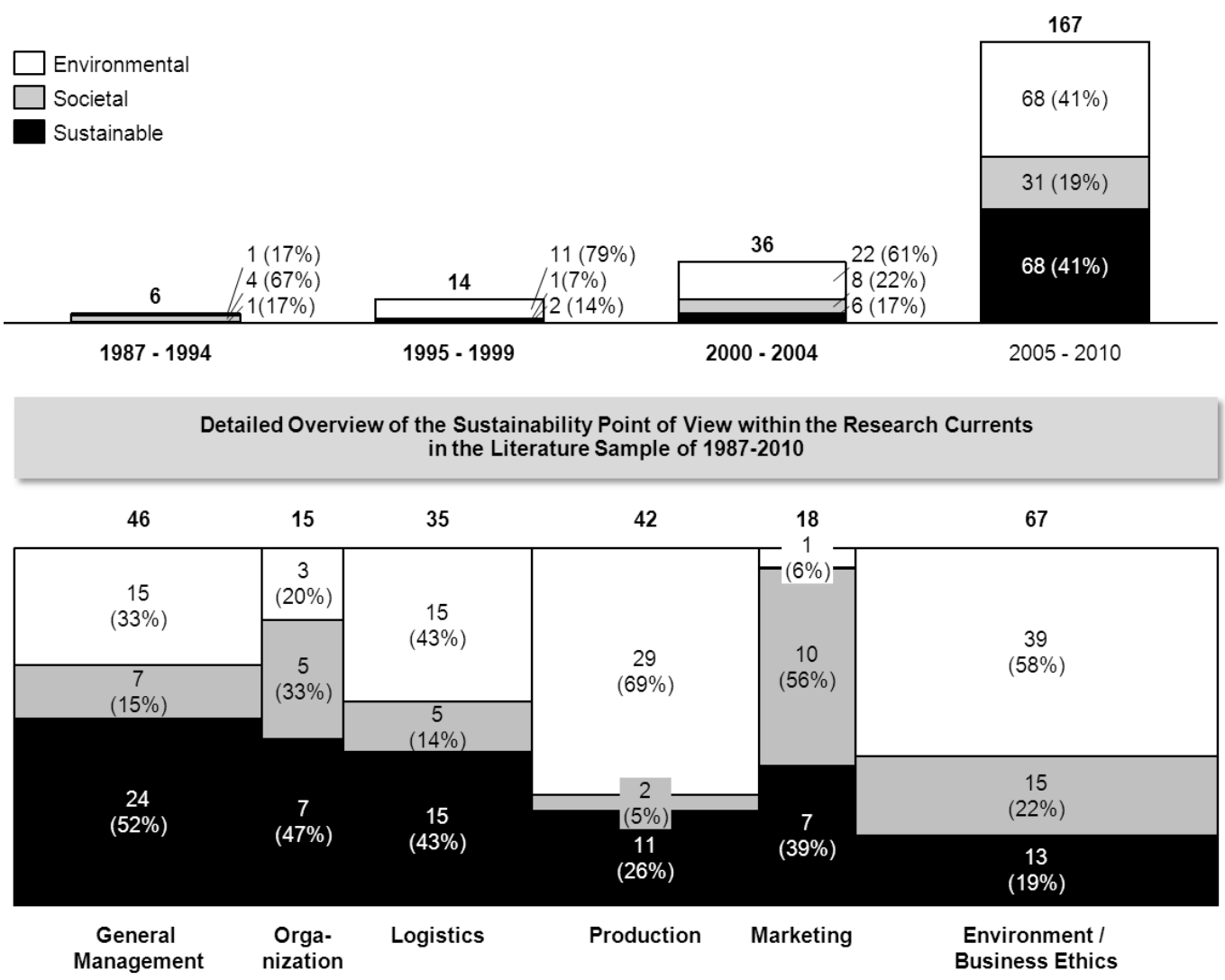

Figure 3: Sustainability Point of View

The described reductive content analysis leads to the following five relevant topics in SSCM research:

1. "Sustainability Concepts and Frameworks" deals with the theoretical derivation or empirical testing of the association of dimensions of sustainability, or exogenous and endogenous influences.

2. "Sustainability and Financial Performance" analyzes the economic success of sustainability strategies or activities.

3. "Sustainability Performance Measurement" copes with indicators for sustainability performance, their reporting and benchmarks.

4. "Operationalization of Sustainability" considers the integration of sustainability into business strategies, encompassing all managerial activities and operative measures of enterprises and supply chains in a sustainability context.

5. "Sustainability Policies and Standards" developed subsequently from operationalization approaches dealing with code of conducts, international standards and the legitimacy of sustainability.

The named topics are partly closely related or hold significant interfaces. Whereas theoretical frameworks can be delimited easier, "sustainability and financial performance" and "sustainability performance measurement" are distinguished on the type of considered perfor- 
mance. The first topic deals with the business case and economic outcomes of sustainable engagement. The subsequent topic concerns the measurement and definition of performance indicators for either all sustainability dimensions, environmental sustainability or societal sustainability. Both topics are also closely related with "sustainability policies and standards". Beyond performance measurement, this topic contemplates regulations, policies and international managerial standards. The broadest topic among the five is "operationalization of sustainability". On the one hand, it summarizes the different nuances of the research currents. On the other hand, the generalization of various managerial actions and operative eco- and socio-efficient measures leads to a broad research topic and thus, a higher number of results.

Figure 4 presents the distribution of the topics over time and in total. "Operationalization" and "performance measurement" amount to $32 \%$ and $21 \%$ of all publications and thus, play the major roles. The research field of "operationalization" holds the largest proportion in all time ranges. The development shows a strong managerial relevance of SSCM research and may indicate an inductive and explorative origin. Publications regarding to "sustainability performance measurement" as well as on theoretical frameworks, on the other hand, have significantly increased in the past 10 years. Although, "sustainability and financial performance" as well as "policies and standards" have the lowest absolute hits, their relevancy has strongly increased within the latest time range. Both developments may be explained by a stronger implementation of CSR and SSCM in practice.

Sustainability Concepts and Frameworks

Sustainability and Financial Performance

Sustainability Performance Measurement

Operationalization of Sustainability

Sustainability Policies and Standards

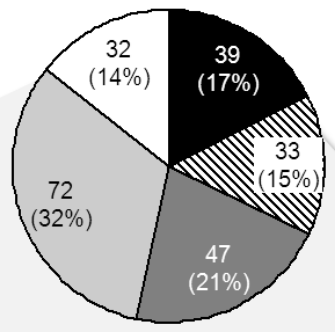

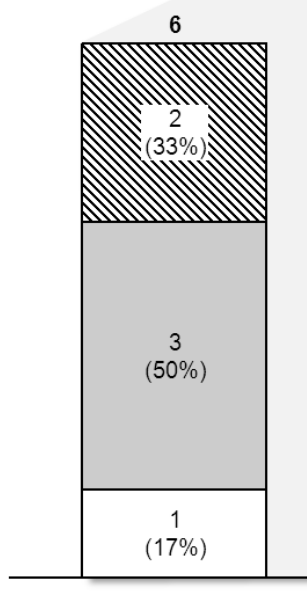

$1987-1994$

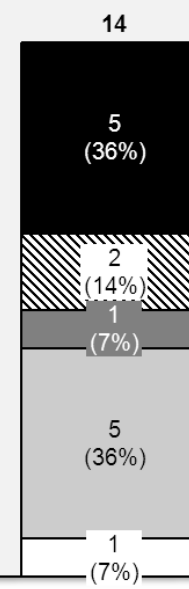

$1995-1999$

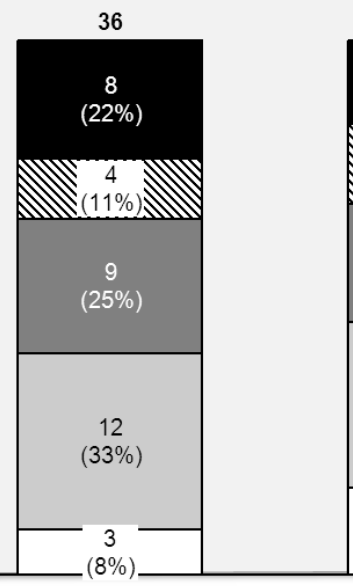

$2000-2004$

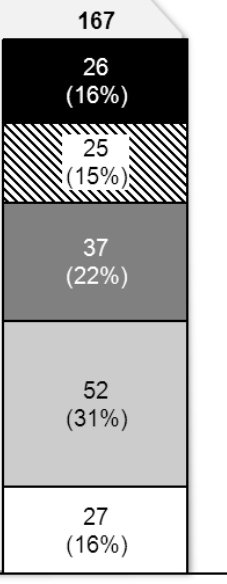

$2005-2010$

Figure 4: Relevant Topics in Sustainability Supply Chain Management Research 


\subsubsection{Sustainability Concepts and Frameworks}

Research on sustainability concepts and frameworks amounts to $17 \%$ of the publications in the sample and can be distinguished regarding to theoretical approaches and frameworks as well as managerial concepts. Both research streams have in common, that they are based on comprehensive analyses of motivations and drivers for sustainable entrepreneurship following the question: why companies go green? Whereas Bansal/Roth (2000), Campbell (2007) and Aguilera et al. (2007) derived motivations from institutional theory, further research in the field is often practice based and aims at understanding managerial decision making processes (e.g. Baron 2001; Cespa/Cestone 2007; Basu/Palazzo 2008).

Theoretical approaches and frameworks differ strongly regarding to their background and objectives. They range from descriptive approaches explaining paradigms or contrasting perspectives on sustainability (e.g. Gladwin et al. 1995; Shrivastava 1995; Windsor 2006; Scherer/Palazzo 2007) to classifying approaches, as for instance, the framework of explicit and implicit CSR by Matten/Moon (2008), to finally illustrating approaches such as the multi-level web of Starik/Rands (1995).

All of these research works cope with intraorganizational CSR concepts, whereas interorganizational SSCM frameworks are still relatively young, so that only three SSCM frameworks were identified in the sample. Carter/Rogers (2008) based their framework on a comprehensive literature review and integrated strategy, organizational culture, transparency and risk management to the triple bottom line concept. In comparison, Seuring/Müller (2008) also conducted a comprehensive literature review and developed a framework of three parts: triggers for SSCM, supplier management for risk and performance and SCM for sustainable products. Finally, Pagell/Wu (2009) applied case study research to develop a model of sustainable SCM practices, which centers the managerial orientation towards sustainability, transparency in the supply chain and aims at an increase of sustainability outcomes. The short summary of the three frameworks points out several similarities, such as the superior role of organizational culture or the relevance of transparency and risk and performance management. Therefore, the further development of SSCM frameworks demands for comprehensive research on the convergence of sustainability and SCM concepts. First steps in this direction are done, but they often specify on either the environmental (e.g. Thun/Müller 2010) or the societal dimension (e.g. Carter/Jennings 2002a).

Above this, there is a large amount of publications coping with managerial concepts, implying the integration of especially environmental management practices to SCM (e.g. Faisal 2010; Halldórsson/Kovács 2010). In this context, scholars classified especially proactive, moderate, conservative or reactive strategy types of firms (Murphy et al. 1996).

As a conclusion from in-depth analysis of concepts and frameworks, current research works still center either only on one point of view of sustainability or struggle with the complexity of the field. Integrating frameworks for sustainability and SCM based on organizational theories and with the ability to explain diverse phenomena of SSCM are still lacking in research.

\subsubsection{Sustainability and Financial Performance}

Research on the coherence of sustainability and financial performance amounts to $15 \%$ of the research activities in the field. Its strong increase in the past five years can be traced back to the discussion, on the business case for sustainability. That implies the relationship of 
sustainability strategies and economic success as well as the customers' willingness to pay for sustainable, green or fair-trade products (e.g. Casadesus-Masanell et al. 2009; Toolsema 2009).

The topic was often in focus of empirical research or modeling approaches. McGuire et al. (1988) were the first within our literature sample to analyze CSR and financial performance. Their research based on a dataset from the perception of CSR reputation of the Fortune Magazine and accounting as well as stock-market based measures of firm performance. As a result, they found accounting-based measures, such as the return on assets, are better predictors of CSR than market-based measures and that the relationship to prior performance is worth more consideration in research. Furthermore, they identified "the difficulty of measuring that concept and consequent reliance on a limited set of measures" (McGuire et al. 1988, 870). McWilliams/Siegel (2000) pointed out that empirical analysis in the field often lacks the contemplation of investments in research and development (R\&D) and hypothesize a significant correlation between CSR and R\&D activities. Barnett/Salomon (2006) met their requirements and analyzed the link to socially responsible investing and found a curvilinear relationship. Recent research activities contemplated especially consequences for the shareholder-value of the firm (e.g. Godfrey et al. 2009).

A further question dealt with in this context, is the coherence of products specifics, CSR and economic performance. Siegel/Vitaliano $(2007,790)$ came to the conclusion, that enterprises "(...) selling experience and credence goods are more likely to be socially responsible than firms selling search goods." The modeling approaches also aim at explaining the business case of sustainability: Barnett (2007), for instance, argued for a stronger stakeholderintegration, whereas Baron $(2007,684)$ who based his model on Milton Friedman's provocative saying that the business of business is business, identified “ (...) conditions under which social entrepreneurs would create CSR firms at a financial loss and explains why those firms can coexist with profit-maximizing firms". Mackey et al. (2007, 833) considered idealistic management-decisions and their effect on firm performance and concluded that "If the demand for socially responsible investment opportunities generated by these investors is greater than the supply of these investment opportunities, then such investments can create economic value for a firm."

Most publications within this research topic stem from "general management" and "marketing" and are predominantly from a CSR point of view. The marketing perspective focuses on the analysis of customer behaviors towards socially responsible companies (e.g. Sen/Bhattacharya 2001; Klein/Dawar 2004; Hardeep/Sharma 2006). However, sustainability and financial performance on a supply chain level has only rarely been analyzed yet. The only approaches in a supply chain context are by Sheu et al. (2005), who designed a optimizationbased model to deal with integrated logistics operational problems of green SCM, and Carter (2005), who analyzed the impact of purchasing social responsibility on the suppliers performance and organizational learning and thus, subsequently on supplier costs.

Therefore, future research may analyze the economic success of the focal firm and its $1^{\text {st }}$, $2^{\text {nd }}$ or even $3^{\text {rd }}$ tier suppliers in the context of all dimensions of sustainability supply chain initiatives. Furthermore, the topic is closely linked to sustainability performance measurement. Hence, sufficient models and benchmarks on sustainability performance need to be created and tested in the context of firm performance in the future. 


\subsubsection{Sustainability Performance Measurement}

The development in Figure 4 as well as the previously described research topics indicates that performance measurement offers vast potentials for future research. Unclear definitions and interpretation varieties are inevitably linked to difficulties in measurement. This is especially true for sustainability performance. Research in the field accounts for $21 \%$ in our sample, but focuses often either on environmental or social performance indicators.

The largest group of publications deals with environmental performance indicators. This group is dominated by case studies or modeling approaches on life-cycle-assessment (LCA) and greenhouse gas emission determination (e.g. Kraines 2002; Sonesson/Berlin 2003; Tan/ Khoo 2005; Matos/Hall 2007).

According to the number of publications, it becomes clear, that greenhouse gas emissions, as one specific environmental indicator, play the superior role in environmental reporting. Especially within the research current "production" numerous decision-models for supply chains, relating environmental and economic indicators are developed (e.g. Kainuma/Tawara 2006; Schmidt/Schwegler 2008; Tsoulfas/Pappis 2008; Tsai/Hung 2009). Vachon/ Klassen $(2006,661)$ tested the influence of interorganizational collaboration on supply chain performance indicators and environmental performance and found that “(...) green project partnership with customers was positively linked to quality, flexibility and environmental performance while partnership with suppliers was associated with better delivery performance."

In comparison to the environmental point of view, the social and sustainable perspective is still vastly unexplored. Hutchins/Sutherland (2008) are the first and only within our sample to determine social measures and impacts throughout the supply chain. They adapted the framework of the United Nations Division of Sustainable Development, which described six categories of social sustainability, namely equity, health, education, housing, security and population. Based on this framework they defined: labor equity, healthcare, safety and philanthropy as social indicators on a supply chain level and described them exemplary.

Hence, performance measurement encompassing all dimensions of sustainability leaves great opportunities for future research. Existing approaches are strongly interrelated to the coherence of sustainability and financial performance and simplify social and environmental performance measurement. Amekudzi et al. (2009), for instance, developed a sustainability footprint model to analyze the impact of transportation and infrastructure systems on regional sustainable development based on the simplified indicators quality of life, waste generation and resource usage.

The development of sufficient and comprehensive sustainability performance indicators is especially important, when it comes to interorganizational supply chain networks. Therefore, future research needs to consider interorganizational sustainability information exchange and reporting standards as key issues for performance measurement and indicator definition (e.g. Roth/Kåberger 2002; Petrini/Pozzebon 2009; Melville 2010; Tate et al. 2010; Watson et al. 2010a).

\subsubsection{Operationalization of Sustainability}

The field "operationalization of sustainability" is the broadest among the five clusters and focuses on the implementation of sustainability strategies into management, corporate actions and measures. Therefore, it analyzes implementation success factors and issues, but 
also functional processes, such as product design and development, purchasing, reverse logistics and closed-loop supply chains.

It is not astonishing that the operationalization context is dominated by case study and empirical research. Environmental issues are prevalent, so that green SCM holds a significant ratio on publications within the field (e.g. Zhu et al. 2007; Darnall et al. 2008; Sheu 2008; Zhu 2008; Mollenkopf et al. 2010; Solér et al. 2010).

Central issues are reverse logistics or closed-loop SCM as well as waste management (e.g. Bevilacqua et al. 2007; Chung/Wee 2008; Bansal/McKnight 2009; Quariguasi Frota Neto et al. 2010). Furthermore, green product design, development and marketing play major roles. For instance, Chialin $(2001,250)$ modeled “(...) the interactions among the customers preferences, the producers product strategies and the environmental standards imposed by the governments."

Finally, sustainable products imply sustainable purchasing activities within the supply chain. Therefore, purchasing is of major relevance to SSCM activities (e.g. Preuss 2001; Carter 2004; Carter/Jennings 2004; Reuter et al. 2010, Krause et al. 2009). Pagell et al. $(2010,70)$ also explored sustainability purchasing and conducted case study research on the basis of Kraljic's purchasing portfolio. They found that “(...) when organizations pursue common prosperity as part of a larger effort to create a sustainable supply chain, they will make investments in supplier continuity that seem to contradict to existing purchasing portfolio models." This contradiction is linked with research gaps concerning the integration of suppliers to sustainability strategies, as for instance the design of incentives, sustainability in supplier management and contract design, but also SSCM performance measurement, which is related to policies and standards in supply chains.

\subsubsection{Sustainability Policies and Standards}

"Sustainability policies and standards" is the topic with the strongest escalation in the literature sample within the past five years. Most publications stem from environmental and business ethics journals. The topic deals with voluntary sustainability initiatives, standards or codes of conducts as well as with governmentally induced policies. Therefore, it combines operationalization, purchasing, performance measurement as well as controlling issues.

These compliance issues, are for example analyzed by Jiang (2009), who contemplated hierarchy and relational norms as governance mediators. Meisner Rosen et al. (2002) derived success factors of voluntary industry standards, whereas Müller et al. 2009; Nawrocka et al. (2009) or Castka/Balzarova (2008a; 2008b) deal with the implementation and impact of code of conducts and ISO standards (14000, 26000). In contrast to both, Sobczak (2006), critically investigated the voluntariness of code of conducts and related them to policies.

The latter are mostly contemplated from a design point of view. Scholars in the field of policies mostly contemplate the right choice and height of environmental or social policies, as for instance the internalization of external effects by taxes or emission trading (e.g. Saint Jean 2008; Chen/Sheu 2009).

\subsection{Intra- versus Interorganizational Sustainability Research}

As we have seen from the analysis, research on SSCM is in a strongly developing, but early stage. In order to map this development, the review comprises sustainability research from 
its beginning within intraorganizational CSR towards interorganizational SSCM approaches.

According to Sharma (2002, 9-10) sustainability research can be distinguished regarding to different levels of analysis: a global, institutional, interorganizational, organizational and individual level. He defines the global level as a macro-level dealing with the interdependence of the "(...) political economy of the environment in an international system involving relationships between firms, NGOs and governments.” The institutional level deals with “(...) interactions between state, federal and local agencies responding to (...) environmental issues." The interorganizational level is described as “(...) research in networks and alliance development among firms, citizens, governments and NGOs (...)." A definite distinction among the three levels is relatively complex. Hence, we summarize all three levels under the term "interorganizational" within this review. On the other hand, the term "intraorganizational" comprises Sharma's organizational and individual levels, which elucidate the role of organizational structures and outcomes as well as the role of individual behavior within organizations.

Due to the selected keywords in the review, an analysis of the intra- and interorganizational perspective is reasonable for the five SCM related research currents. The results of this analysis are given in Table 5. All publications of "environmental and business ethics" journals are excluded, since they were searched regarding to the keyword "supply chain" and thus, include an interorganizational perspective.

The figures underline that the interorganizational perspective has significantly increased in the time range 2005-2010. The escalation is especially caused by the supply chain-orientation of the research currents "logistics" and "production". On the one hand, the analysis underlines the ongoing convergence of the sustainability and the supply chain concept. On the other hand, the figures identify a lack of interorganizational and thus, supply chain related research in "general management", "organization" and "marketing”.

\begin{tabular}{lcccc}
\hline Intraorganizational / Interorganizational Perspective & & & \\
\hline Research Current & $1987-1994$ & $1995-1999$ & $2000-2004$ & 2005-2010 \\
\hline General Management & $1 / 0$ & $5 / 2$ & $9 / 0$ & $21 / 8$ \\
\hline Organization & $1 / 1$ & $0 / 0$ & $1 / 0$ & $9 / 3$ \\
\hline Logistics & $0 / 1$ & $2 / 0$ & $2 / 4$ & $9 / 17$ \\
\hline Production & $0 / 0$ & $2 / 0$ & $1 / 3$ & $15 / 21$ \\
\hline Marketing & $2 / 0$ & $1 / 0$ & $4 / 0$ & $9 / 2$ \\
\hline Total & $4 / 2$ & $10 / 2$ & $17 / 7$ & $63 / 51$ \\
\hline
\end{tabular}

Table 5: Intra- and Interorganizational Research within Research Currents

\section{Implications for Future Research and Conclusion}

A central objective of this review is to derive implications for future research in SSCM. In this context, descriptive and categorizing research questions were answered by the means of quantitative and qualitative analysis.

The literature sample underlines the recent popularity of sustainability research. Although, the time range comprises the years 1987 to 2010,167 out of 223 publications stem from the 
last 6 years. Within this time range, we identified a paradigm change towards the term sustainability instead of CSR. From a methodological point of view, the dominance of qualitative research pointed out the still developing status of the research field. However, sufficient conceptual and theoretical approaches are still underrepresented. Furthermore, strongly diverging pictures within the research currents were presented in terms of methodology application and relevancy. Especially "organizational" and "marketing" literature lacks CSR and sustainability publications and may be of interest for more cross-functional research. Subsequently, we analyzed the sustainability point of view and found a historically driven vast majority dealing with environmental issues. Although, the call of various researchers for more integrated research on sustainability leads to a more tripartite picture within the latest time cluster, comprehensive sustainability research and in-depth work on the social dimension need to remain in the focus of scholars to advance the field.

By the means of content analysis, five major research topics are identified in the literature sample: "Sustainability Concepts and Frameworks", "Sustainability and Financial Performance", "Sustainability Performance Measurement", "Operationalization of Sustainability" and "Sustainability Policies and Standards". The coherences between the research topics as well as the developing status of interorganizational sustainability research hold diverse opportunities for future research.

Firstly, comprehensive conceptual SSCM frameworks are still underrepresented. Therefore, the integration of supply chain and sustainability concepts demands for extended research effort, especially from an organizational theory point of view. The supply chain perspective may also be linked with the research on "Sustainability and Financial Performance". The analysis of the interdependency of sustainability strategies and its influences on the financial performance of the supply chain network is still lacking. This knowledge is especially needed for incentive design within buyer-supplier relationships and supply chains. Additionally, the customer's willingness to pay and its consequences for the degree of implementation of SSCM may be of academic and managerial interest. The proposed development and relevancy of the interorganizational perspective also demands for comprehensive and sufficient sustainability performance indicators and measurement techniques to solve transparency and information asymmetries by, for instance, reporting tools and information technology. Finally, sustainable supply chains demand for sufficient sustainability purchasing principles, supplier selection criteria and governance structures and thus, demand for research on code of conduct design and industrial standards. Against this background, research may contemplate interdependencies between regulations, economic success and behavior of supply chain members. Considering sustainable global supply chains, cultural differences or product specifics may be of interest in future research works.

The literature review highlights that the convergence of sustainability and SCM research is of high academic and managerial interest, but also highly requires research on SSCM theory building, the identification of sufficient sustainability performance indicators, the operationalization of sustainability within supply chain networks (implying supplier selection and development, policies and standards) as well as financial and behavioral impacts of sustainability efforts within the supply chain. 


\section{Appendix}

\begin{tabular}{|c|c|c|}
\hline $\begin{array}{l}\text { Sustainability Concepts } \\
\text { and Frameworks } \\
(\mathbf{n}=39)\end{array}$ & $\begin{array}{l}\text { Sustainability and } \\
\text { Financial Performance } \\
(\mathbf{n}=33)\end{array}$ & $\begin{array}{l}\text { Sustainability Performance } \\
\text { Measurement } \\
(\mathrm{n}=47)\end{array}$ \\
\hline Aguilera et al. 2007 & Barnett/Salomon 2006 & Amekudzi et al. 2009 \\
\hline Bansal/Roth 2000 & Barnett 2007 & Bai/Sarkis 2010 \\
\hline Baron 2001 & Baron 2007 & Carter/Jennings 2002b \\
\hline Basu/Palazzo 2008 & Calveras et al. 2007 & Chatterji et al. 2009 \\
\hline Bowen et al. 2001 & Calvo et al. 2008 & Ciliberti et al. $2008 \mathrm{~b}$ \\
\hline Campbell 2007 & Carter/Rogers 2008 & Cooper et al. 2000 \\
\hline Carter/Jennings 2002a & $\begin{array}{l}\text { Casadesus-Masanell et al. } \\
2009\end{array}$ & Dou/Sarkis 2009 \\
\hline Carter/Rogers 2008 & Chin-Shan et al. 2009 & Ernult/Ashta 2008 \\
\hline Caruana/Crane 2008 & Crouch 2006 & Fernandez-Kranz/Santalo 2010 \\
\hline Cespa/Cestone 2007 & Doh/Guay 2006 & Geldermann et al. 2007 \\
\hline Cruz/Wakolbinger 2008 & Endress et al. 2005 & Handfield et al. 2005 \\
\hline Cruz/Matsypura 2009 & $\begin{array}{l}\text { Garcia-Gallego/Georgantzís } \\
2009\end{array}$ & Hutchins/Sutherland 2008 \\
\hline Faisal 2010 & Godfrey et al. 2009 & Isaksson et al. 2010 \\
\hline Giacalone et al. 2008 & Hardeep/Sharma 2006 & Kainuma/Tawara 2006 \\
\hline Gladwin et al. 1995 & Hunt et al. 1990 & King/Lenox 2001 \\
\hline Halldórsson/Kovács 2010 & Klein/Dawar 2004 & Kim et al. 2010 \\
\hline Jennings/Zandbergen 1995 & Lichtenstein et al. 2004 & Kovács 2008 \\
\hline Kleindorfer et al. 2005 & Harrison/Freeman 1999 & Kraines 2002 \\
\hline Linton et al. 2007 & Luo/Bhattacharya 2006 & Li et al. 2009 \\
\hline Lockett et al. 2006 & Mackey et al. 2007 & Lu et al. 2007 \\
\hline Maignan/Ferrell 2004 & McGuire et al. 1988 & Markley/Davis 2007 \\
\hline Matten/Moon 2008 & McWilliams/Siegel 2000 & Matos/Hall 2007 \\
\hline McWilliams/Siegel 2001 & Sanchez-Rodrigues et al. 2010 & O Brien 1999 \\
\hline Murphy et al. 1996 & Sen/Bhattacharya 2001 & Pagell/Gobeli 2009 \\
\hline Melville 2010 & Sen et al. 2006 & Petrini/Pozzebon 2009 \\
\hline Pagell et al. 2008 & Sheu et al. 2005 & Presley et al. 2007 \\
\hline Pagell/Wu 2009 & Shuili et al. 2007 & Pullman et al. 2009 \\
\hline Pagell et al. 2010 & Siegel/Vitaliano 2007 & $\begin{array}{l}\text { Quariguasi Frota Neto et al. } \\
2008\end{array}$ \\
\hline
\end{tabular}




\begin{tabular}{|c|c|c|}
\hline $\begin{array}{l}\text { Sustainability Concepts } \\
\text { and Frameworks } \\
(\mathrm{n}=39)\end{array}$ & $\begin{array}{l}\text { Sustainability and } \\
\text { Financial Performance } \\
(\mathbf{n}=33)\end{array}$ & $\begin{array}{l}\text { Sustainability Performance } \\
\text { Measurement } \\
(\mathrm{n}=47)\end{array}$ \\
\hline Rodriguez et al. 2006 & Singhapakdi et al. 1995 & $\begin{array}{l}\text { Quariguasi Frota Neto et al. } \\
2010\end{array}$ \\
\hline Scherer/Palazzo 2007 & Surroca et al. 2010 & Rothenberg et al. 2001 \\
\hline Seuring 2004b & Toolsema 2009 & Salam 2009 \\
\hline Seuring/Müller 2008b & van Hoek/Johnson 2010 & Schliephake et al. 2009 \\
\hline Shrivastava 1995 & Vlachos et al. 2009 & Schmidt/Schwegler 2008 \\
\hline Smith 2009 & & Sonesson/Berlin 2003 \\
\hline Starik/Rands 1995 & & Strike et al. 2006 \\
\hline Thun/Müller 2010 & & Tan/Khoo 2005 \\
\hline Windsor 2006 & & Tate et al. 2010 \\
\hline Yadong 2006 & & Tsai/Hung 2009 \\
\hline \multirow[t]{9}{*}{ Young 2000} & & Tsoulfas/Pappis 2006 \\
\hline & & Tsoulfas/Pappis 2008 \\
\hline & & Vachon/Mao 2008 \\
\hline & & van der Vorst et al. 2009 \\
\hline & & Whatling et al. 2010 \\
\hline & & Yedla/Shrestha 2003 \\
\hline & & Zhu/Cote 2004 \\
\hline & & Zhu/Sarkis 2004 \\
\hline & & Zhu et al. 2008 \\
\hline
\end{tabular}

Table 6: Literature Sample: Clusters of relevant Research Topics in SSCM (Part I/II)

\begin{tabular}{lll}
\hline $\begin{array}{l}\text { Operationalization } \\
\text { of Sustainability } \\
(\mathbf{n}=\mathbf{7 2})\end{array}$ & $\begin{array}{l}\text { Sustainability Polices and Stan- } \\
\text { dards } \\
(\mathbf{n}=32)\end{array}$ \\
\hline Arnold/Bowie 2007 & Lieb/Lieb 2010 & Amaeshi et al. 2008 \\
\hline Bansal 2005 & Luchs et al. 2010 & Castka/Balzarova 2008b \\
\hline Bansal/McKnight 2009 & Maignan/Ralston 2002 & Castka/Balzarova 2008a \\
\hline Bevilacqua et al. 2007 & Mamic 2005 & Chen et al. 2009 \\
\hline Böhler et al. 2006 & Meisner Rosen et al. 2000 & Côté et al. 2008 \\
\hline Branzei et al. 2004 & Melville 2010 & Doh/Guay 2006 \\
\hline Brown 1991 & Mollenkopf et al. 2010 & Etzion/Ferraro 2010 \\
\hline
\end{tabular}




\begin{tabular}{|c|c|c|}
\hline $\begin{array}{l}\text { Operationalization } \\
\text { of Sustainability } \\
(\mathbf{n}=72)\end{array}$ & & $\begin{array}{l}\text { Sustainability Polices and Stan- } \\
\text { dards } \\
(\mathrm{n}=32)\end{array}$ \\
\hline Budeanu 2009 & Preuss 2005 & Font et al. 2008 \\
\hline Butler 2011 & Prieto-Carrón 2008 & Georgiadis/Besiou 2008 \\
\hline Carter 2004 & Reiskin et al. 1999 & Ijomah et al. 2007 \\
\hline Carter/Jennings 2004 & Reuter et al. 2010 & Irland 2007 \\
\hline Chialin 2001 & Roberts 2003 & Jiang 2009 \\
\hline Ciliberti et al. 2008a & Robin/Reidenbach 1987 & Koplin et al. 2007 \\
\hline Caruana/Crane 2008 & Russo 2003 & Maloni/Brown 2006 \\
\hline Cramer 2008 & Seuring et al. 2008 & Meisner Rosen et al. 2002 \\
\hline Darnall et al. 2008 & Seuring/Müller 2008a & Mintcheva 2005 \\
\hline Brito et al. 2008 & Seuring 2009 & Müller et al. 2009 \\
\hline Diniz/Fabbe-Costes 2007 & Sharma/Henriques 2005 & Nawrocka et al. 2009 \\
\hline Evans et al. 2007 & Sheu 2008 & Newton/Harte 1997 \\
\hline Faruk et al. 2001 & Smith et al. 2010 & Nijkamp 1994 \\
\hline Fineman/Clarke 1996 & Solér et al. 2010 & Park-Poaps/Rees 2010 \\
\hline Hall 2000 & Starkey/Crane 2003 & Preuss 2001 \\
\hline Hall/Matos 2010 & Strand 2009 & Quak/De Koster 2007 \\
\hline Handfield et al. 1997 & Vachon/Klassen 2006 & Saint Jean 2008 \\
\hline Horio/Watanabe 2008 & Vachon/Klassen 2006 & Sarkis 2003 \\
\hline Hu/Bidanda 2009 & Vachon 2007 & Sharfman et al. 2009 \\
\hline Hugo/Pistikopoulos 2005 & van Tulder et al. 2009 & Sigala 2008 \\
\hline Husted/Allen 2006 & Vurro et al. 2009 & Sobczak 2006 \\
\hline Jauhari 2005 & Waldman et al. 2006b & Wagner et al. 2009 \\
\hline Khan et al. 2010 & Waldman et al. 2006a & Zhu/Sarkis 2006 \\
\hline King/Lenox 2001 & Watson et al. 2010a & Zhu/Sarkis 2007 \\
\hline Kortelainen 2008 & Watson et al. $2010 \mathrm{~b}$ & Zhu et al. 2007 \\
\hline Krause et al. 2009 & Wee/Chung 2009 & \\
\hline Krueger 2008 & Wu/Dunn 1995 & \\
\hline Lee et al. 2010 & Wycherley 1999 & \\
\hline Li et al. 2010 & Zhu 2008 & \\
\hline
\end{tabular}

Table 7: Literature Sample: Clusters of relevant Research Topics in SSCM (Part II/II) 


\section{References}

Aguilera, R.V., et al. (2007): Putting the S back in Corporate Social Responsibility: A multilevel Theory of social Change in Organizations, in: Academy of Management Review, Vol. 32, No. 3, pp. 836-863.

Amaeshi, K.M., et al. (2008): Corporate Social Responsibility in Supply Chains of Global Brands: A Boundaryless Responsibility? Clarifications, Exceptions and Implications, in: Journal of Business Ethics, Vol. 81, No. 1, pp. 223-234.

Amekudzi, A.A., et al. (2009): Using the Sustainability Footprint Model to assess Development Impacts of Transportation Systems, in: Transportation Research Part A: Policy \& Practice, Vol. 43, No. 4, pp. 339-348.

Arnold, D.G./Bowie, N.E. (2007): Respect for Workers in global Supply Chains: Advancing the Debate over Sweatshops, in: Business Ethics Quarterly, Vol. 17, No. 1, pp. 135-145.

Atteslander, P. (2006): Methoden der empirischen Sozialforschung, Berlin.

Bai, C./Sarkis, J. (2010): Integrating Sustainability into Supplier Selection with Grey System and Rough Set Methodologies, in: International Journal of Production Economics, Vol. 124, No. 1, pp. 252-264.

Bansal, P. (2005): Evolving Sustainably: A longitudinal Study of Corporate Sustainable Development, in: Strategic Management Journal, Vol. 26, No. 3, pp. 197-218.

Bansal, P./McKnight, B. (2009): Looking forward, pushing back and peering sideways: Analyzing the Sustainability of industrial Symbiosis, in: Journal of Supply Chain Management, Vol. 45, No. 4, pp. 26-38.

Bansal, P./Roth, K. (2000): Why Companies go green: A Model of ecological Responsiveness, in: Academy of Management Journal, Vol. 43, No. 4, pp. 717-748.

Barnett, M.L. (2007): Stakeholder Influence Capacity and the Variability of financial Returns to Corporate Social Responsibility, in: Academy of Management Review, Vol. 32, No. 3, pp. 794-816.

Barnett, M.L./Salomon, R.M. (2006): Beyond Dichotomy: The curvilinear Relationship between social Responsibility and financial Performance, in: Strategic Management Journal, Vol. 27, No. 11, pp. 1101-1122.

Baron, D.P. (2001): Private Politics, Corporate Social Responsibility and integrated Strategy, in: Journal of Economics \& Management Strategy, Vol. 10, No. 1, pp. 7-45.

Baron, D.P. (2007): Corporate Social Responsibility and Social Entrepreneurship, in: Journal of Economics \& Management Strategy, Vol. 16, No. 3, pp. 683-717.

Basu, K./Palazzo, G. (2008): Corporate Social Responsibility: A Process Model of Sensemaking, in: Academy of Management Review, Vol. 33, No. 1, pp. 122-136.

Bechtel, C./Jayaram, J. (1997): Supply Chain Management: A Strategic Perspective, in: The International Journal of Logistics Management, Vol. 8, No. 1, pp. 15-34.

Bevilacqua, M., et al. (2007): Development of a sustainable Product Lifecycle in Manufacturing Firms: A Case Study, in: International Journal of Production Research, Vol. 45, No. 18/19, pp. 4073-4098.

Böhler, S., et al. (2006): Encouraging environmentally sustainable Holiday Travel, in: Transportation Research Part A: Policy \& Practice, Vol. 40, No. 8, pp. 652-670.

Bowen, F.E., et al. (2001): The Role of Supply Management Capabilities in Green Supply, in: Production and Operations Management, Vol. 10, No. 2, pp. 174-189. 
Branzei, O., et al. (2004): The Formation of green Strategies in Chinese Firms: Matching Corporate environmental Response and individual Principles, in: Strategic Management Journal, Vol. 25, No. 11, pp. 1075-1095.

Brito, M., et al. (2008): Towards a sustainable Fashion Retail Supply Chain in Europe: Organisation and Performance, in: International Journal of Production Economics, Vol. 114, No. 2, pp. 534-553.

Brown, L.D. (1991): Bridging Organizations and Sustainable Development, in: Human Relations, Vol. 44, No. 8, pp. 807-831.

Budeanu, A. (2009): Environmental Supply Chain Management in Tourism: The Case of large Tour Operators, in: Journal of Cleaner Production, Vol. 17, No. 16, pp. 1385-1392.

Butler, T. (2011): Compliance with institutional Imperatives on environmental Sustainability: Building Theory on the Role of Green IS, in: The Journal of Strategic Information Systems, Vol. 20, No. 1, pp. 6-26.

Calveras, A., et al. (2007): Regulation, Corporate Social Responsibility and Activism, in: Journal of Economics \& Management Strategy, Vol. 16, No. 3, pp. 719-740.

Calvo, R., et al. (2008): Systemic Criterion of Sustainability in agile Manufacturing, in: International Journal of Production Research, Vol. 46, No. 12, pp. 3345-3358.

Campbell, J.L. (2007): Why would Corporations behave in socially responsible Ways? An institutional Theory of Corporate Social Responsibility, in: Academy of Management Review, Vol. 32, No. 3, pp. 946-967.

Carroll, A.B. (1991): The Pyramid of Corporate Social Responsibility: Toward the moral Management of organizational Stakeholders, in: Business Horizons, Vol. 34, No. 4, pp. 39-48.

Carter, C.R. (2004): Purchasing and Social Responsibility: A Replication and Extension, in: Journal of Supply Chain Management: A Global Review of Purchasing \& Supply, Vol. 40, No. 4, pp. 4-16.

Carter, C.R. (2005): Purchasing Social Responsibility and Firm Performance: The Key mediating Roles of organizational Learning and Supplier Performance, in: International Journal of Physical Distribution \& Logistics Management, Vol. 35, No. 3/4, pp. 177-195.

Carter, C.R./Jennings, M.M. (2002a): Logistics Social Responsibility: An integrative Framework, in: Journal of Business Logistics, Vol. 23, No. 1, pp. 145-181.

Carter, C.R./Jennings, M.M. (2002b): Social Responsibility and Supply Chain Relationships, in: Transportation Research Part E: Logistics and Transportation Review, Vol. 38, No. 1, pp. 37-52.

Carter, C.R./Jennings, M.M. (2004): The Role of Purchasing in Corporate Social Responsibility: A structural Equation Analysis, in: Journal of Business Logistics, Vol. 25, No. 1, pp. 145-187.

Carter, C.R./Rogers, D.S. (2008): A Framework of sustainable Supply Chain Management: moving toward new Theory, in: International Journal of Physical Distribution \& Logistics Management, Vol. 38, No. 5, pp. 360-387.

Caruana, R./Crane, A. (2008): Constructing Consumer Responsibility: Exploring the Role of Corporate Communications, in: Organization Studies, Vol. 29, No. 12, pp. 1495-1519.

Casadesus-Masanell, R., et al. (2009): Households' Willingness to pay for "Green" Goods: Evidence from Patagonia's Introduction of organic Cotton Sportswear, in: Journal of Economics \& Management Strategy, Vol. 18, No. 1, pp. 203-233.

Castka, P./Balzarova, M. (2008a): The Impact of ISO 9000 and ISO 14000 on Standardisation of Social Responsibility-an inside Perspective, in: International Journal of Production Economics, Vol. 113, No. 1, pp. 74-87. 
Castka, P./Balzarova, M. (2008b): ISO 26000 and Supply Chains - On the Diffusion of the Social Responsibility Standard, in: International Journal of Production Economics, Vol. 111, No. 2, pp. 274-286.

Cespa, G./Cestone, G. (2007): Corporate Social Responsibility and managerial Entrenchment, in: Journal of Economics \& Management Strategy, Vol. 16, No. 3, pp. 741-771.

Chatterji, A.K., et al. (2009): How well do social Ratings actually measure Corporate Social Responsibility?, in: Journal of Economics \& Management Strategy, Vol. 18, No. 1, pp. 125-169.

Chen, H., et al. (2009): Supply Chain Process Integration: A theoretical Framework, in: Journal of Business Logistics, Vol. 30, No. 2, pp. 27-48.

Chen, Y.J./Sheu, J.-B. (2009): Environmental-Regulation Pricing Strategies for green Supply Chain Management, in: Transportation Research Part E: Logistics and Transportation Review, Vol. 45, No. 5, pp. 667-677.

Chialin, C. (2001): Design for the Environment: A Quality-Based Model for Green Product Development, in: Management Science, Vol. 47, No. 2, pp. 250-264.

Chin-Shan, L., et al. (2009): Corporate Social Responsibility and organisational Performance in Container Shipping, in: International Journal of Logistics: Research \& Applications, Vol. 12, No. 2, pp. 119-132.

Chung, C./Wee, H. (2008): Green-Component Life-Cycle Value on Design and Reverse Manufacturing in semi-closed Supply Chain, in: International Journal of Production Economics, Vol. 113, No. 2, pp. 528-545.

Ciliberti, F., et al. (2008a): Investigating Corporate Social Responsibility in Supply Chains: A SME Perspective, in: Journal of Cleaner Production, Vol. 16, No. 15, pp. 1579-1588.

Ciliberti, F., et al. (2008b): Logistics Social Responsibility: Standard Adoption and Practices in Italian Companies, in: International Journal of Production Economics, Vol. 113, No. 1, pp. 88-106.

Cooper, M.C., et al. (1997): Supply Chain Management: More Than a New Name for Logistics, in: International Journal of Logistics Management, Vol. 8, No. 1, pp. 1-14.

Cooper, R.W., et al. (2000): A multinational Comparison of key ethical Issues, helps and challenges in the Purchasing and Supply Management Profession: The key Implications for Business and the Professions, in: Journal of Business Ethics, Vol. 23, No. 1, pp. 83-100.

Côté, R.P., et al. (2008): Influences, Practices and Opportunities for environmental Supply Chain Management in Nova Scotia SMEs, in: Journal of Cleaner Production, Vol. 16, No. 15, pp. 1561-1570.

Cramer, J.M. (2008): Organising Corporate Social Responsibility in International Product Chains, in: Journal of Cleaner Production, Vol. 16, No. 3, pp. 395-400.

Crouch, C. (2006): Modelling the Firm in its Market and organizational Environment: Methodologies for studying Corporate Social Responsibility, in: Organization Studies, Vol. 27, No. 10, pp. 1533-1551.

Cruz, J./Matsypura, D. (2009): Supply Chain Networks with Corporate Social Responsibility through integrated environmental Decision-Making, in: International Journal of Production Research, Vol. 47, No. 3, pp. 621-648.

Cruz, J./Wakolbinger, T. (2008): Multiperiod Effects of Corporate Social Responsibility on Supply Chain Networks, Transaction Costs, Emissions, and Risk, in: International Journal of Production Economics, Vol. 116, No. 1, pp. 61-74. 
Darnall, N., et al. (2008): Environmental Management Systems and green Supply Chain Management: Complements for Sustainability?, in: Business Strategy and the Environment, Vol. 17, No. 1, pp. 30-45.

Diniz, J.D.A.S./Fabbe-Costes, N. (2007): Supply Chain Management and Supply Chain Orientation: Key Factors for sustainable Development Projects in developing Countries?, in: International Journal of Logistics: Research \& Applications, Vol. 10, No. 3, pp. 235-250.

Doh, J.P./Guay, T.R. (2006): Corporate Social Responsibility, Public Policy, and NGO Activism in Europe and the United States: An Institutional-Stakeholder Perspective, in: Journal of Management Studies, Vol. 43, No. 1, pp. 47-73.

Dou, Y./Sarkis, J. (2009): A joint Location and Outsourcing Sustainability Analysis for a strategic Offshoring Decision, in: International Journal of Production Research, Vol. 48, No. 2, pp. 567-592.

Dyllick, T./Hockerts, K. (2002): Beyond the Business Case for Corporate Sustainability, in: Business Strategy and the Environment, Vol. 11, No. 2, pp. 130-141.

Elkington, J. (1997): Cannibals with Forks. The Triple Bottom Line of 21st Century Business, Oxford.

Endress, L.H., et al. (2005): Sustainable Growth with environmental Spillovers, in: Journal of Economic Behavior \& Organization, Vol. 58, No. 4, pp. 527-547.

Ernult, J./Ashta, A. (2008): How to measure global sustainable Performance in a Service Enterprise? A Case Study of the Credibility of Vigeos's Rating of Caisse d'Epargne, in: Journal of Services Research, Vol. No. pp. 101-123.

Etzion, D./Ferraro, F. (2010): The Role of Analogy in the Institutionalization of Sustainability Reporting, in: Organization Science, Vol. 21, No. 5, pp. 1092-1107.

Evans, S., et al. (2007): Industrialization as a Key Element of sustainable Product-Service Solutions, in: International Journal of Production Research, Vol. 45, No. 18/19, pp. 4225-4246.

Faisal, M.N. (2010): Analysing the Barriers to Corporate Social Responsibility in Supply Chains: An interpretive structural modelling Approach, in: International Journal of Logistics: Research \& Applications, Vol. 13, No. 3, pp. 179-195.

Faruk, A.C., et al. (2001): Analyzing, Mapping, and Managing environmental Impacts along Supply Chains, in: Journal of Industrial Ecology, Vol. 5, No. 2, pp. 13-36.

Fernandez-Kranz, D./Santalo, J. (2010): When Necessity Becomes a Virtue: The Effect of Product Market Competition on Corporate Social Responsibility, in: Journal of Economics and Management Strategy, Vol. 19, No. 2, pp. 453-487.

Fineman, S./Clarke, K. (1996): Green Stakeholders: Industry Interpretations and Response, in: Journal of Management Studies, Vol. 33, No. 6, pp. 715-730.

Font, X., et al. (2008): Sustainable Supply Chain Management in Tourism, in: Business Strategy and the Environment, Vol. 17, No. 4, pp. 260-271.

Garcia-Gallego, A./Georgantzís, N. (2009): Market Effects of Changes in Consumers' Social Responsibility, in: Journal of Economics \& Management Strategy, Vol. 18, No. 1, pp. 235-262.

Geldermann, J., et al. (2007): Towards sustainable Production Networks, in: International Journal of Production Research, Vol. 45, No. 18/19, pp. 4207-4224.

Georgiadis, P./Besiou, M. (2008): Sustainability in electrical and electronic Equipment closed-loop Supply Chains: A System Dynamics Approach, in: Journal of Cleaner Production, Vol. 16, No. 15, pp. 1665-1678.

Giacalone, R., et al. (2008): On Ethics and social Responsibility: The Impact of Materialism, Postmaterialism, and Hope, in: Human Relations, Vol. 61, No. 4, pp. 483-514. 
Giunipero, L., et al. (2008): A Decade of SCM Literature: Past, present and future Implications, in: Journal of Supply Chain Management, Vol. 44, No. 4, pp. 66-86.

Gladwin, T.N., et al. (1995): Shifting Paradigms for sustainable Development: Implications for Management Theory and Research, in: Academy of Management. The Academy of Management Review, Vol. 20, No. 4, pp. 874-908.

Godfrey, P.C., et al. (2009): The Relationship between Corporate Social Responsibility and Shareholder Value: An empirical Test of the Risk Management Hypothesis, in: Strategic Management Journal, Vol. 30, No. 4, pp. 425-445.

Guba, E.G./Lincoln, Y.S. (1994): Competing Paradigms in Qualitative Research, in: Denzin, N.K./ Lincoln, Y.S. (Ed.): Handbook of Qualitative Research, London, pp. 105-117.

Gudmundsson, H./Höjer, M. (1996): Sustainable Development Principles and their Implications for Transport, in: Ecological Economics, Vol. 19, No. 3, pp. 269-282.

Hall, J. (2000): Environmental Supply Chain Dynamics, in: Journal of Cleaner Production, Vol. 8, No. 6, pp. 455-471.

Hall, J./Matos, S. (2010): Incorporating impoverished Communities in sustainable Supply Chains, in: International Journal of Physical Distribution \& Logistics Management, Vol. 40, No. 1/2, pp. 124-147.

Halldórsson, Á./Kovács, G. (2010): The sustainable Agenda and Energy Efficiency, in: International Journal of Physical Distribution \& Logistics Management, Vol. 40, No. 1/2, pp. 5-13.

Handfield, R.B., et al. (1997): 'Green' Value Chain Practices in the Furniture Industry, in: Journal of Operations Management, Vol. 15, No. 4, pp. 293-315.

Handfield, R.B., et al. (2005): Integrating environmental Management and Supply Chain Strategies, in: Business Strategy and the Environment, Vol. 14, No. 1, pp. 1-19.

Hardeep, C./Sharma, R.D. (2006): Implications of Corporate Social Responsibility on Marketing Performance: A conceptual Framework, in: Journal of Services Research, Vol. 6, No. 1, pp. 205-216.

Harrison, J.S./Freeman, R.E. (1999): Stakeholders, social Responsibility, and Performance: Empirical Evidence and theoretical Perspectives, in: Academy of Management Journal, Vol. 42, No. 5, pp. 479-485.

Hart, C. (1998): Doing a Literature Review: Releasing the Social Science Research Imagination, London.

Horio, H./Watanabe, C. (2008): The Paradox of a service-oriented Economy for Sustainability: CoEvolution between Innovation and Resources Effectuation by a global Complement, in: Journal of Services Research, Vol. 8, No. 1, pp. 155-175.

Hsieh, H.-F./Shannon, S.E. (2005): Three Approaches to Qualitative Content Analysis, in: Qualitative Health Research, Vol. 15, No. 9, pp. 1277-1288.

Hu, G./Bidanda, B. (2009): Modeling sustainable Product Lifecycle Decision Support Systems, in: International Journal of Production Economics, Vol. 122, No. 1, pp. 366-375.

Hugo, A./Pistikopoulos, E.N. (2005): Environmentally conscious long-range Planning and Design of Supply Chain Networks, in: Journal of Cleaner Production, Vol. 13, No. 15, pp. 1471-1491.

Hunt, S.D., et al. (1990): Social Responsibility and Personal Success: A Research Note, in: Journal of the Academy of Marketing Science, Vol. 18, No. 3, pp. 239-244.

Husted, B.W./Allen, D.B. (2006): Corporate Social Responsibility in the multinational Enterprise: Strategic and institutional Approaches, in: Journal of International Business Studies, Vol. 37, No. 6, pp. 838-849. 
Hutchins, M.J./Sutherland, J.W. (2008): An Exploration of Measures of social Sustainability and their Application to Supply Chain Decisions, in: Journal of Cleaner Production, Vol. 16, No. 15, pp. 1688-1698.

Ijomah, W.L., et al. (2007): Development of robust Design-for-Remanufacturing Guidelines to further the Aims of sustainable Development, in: International Journal of Production Research, Vol. 45, No. 18/19, pp. 4513-4536.

Irland, L.C. (2007): Developing Markets for certified Wood Products: Greening the Supply Chain for Construction Materials, in: Journal of Industrial Ecology, Vol. 11, No. 1, pp. 201-216.

Isaksson, R., et al. (2010): Detecting Supply Chain Innovation Potential for sustainable Development, in: Journal of Business Ethics, Vol. 97, No. 3, pp. 425-442.

Jauhari, V. (2005): Information Technology, Corporate Business Firms and sustainable Development, in: Journal of Services Research, Vol. 5, No. 2, pp. 37-76.

Jennings, P.D./Zandbergen, P.A. (1995): Ecologically sustainable Organizations: An institutional Approach, in: Academy of Management. The Academy of Management Review, Vol. 20, No. 4, pp. 1015-1053.

Jiang, B. (2009): Implementing Supplier Codes of Conduct in global Supply Chains: Process Explanations from theoretic and empirical Perspectives, in: Journal of Business Ethics, Vol. 85, No. 1, pp. 77-92.

Kainuma, Y./Tawara, N. (2006): A multiple Attribute Utility Theory Approach to lean and green Supply Chain Management, in: International Journal of Production Economics, Vol. 101, No. 1, pp. 99-108.

Khan, F.R., et al. (2010): 'I feel like a foreign Agent': NGOs and Corporate Social Responsibility Interventions into Third World Child Labor, in: Human Relations, Vol. 63, No. 9, pp. 1417-1438.

Kim, J., et al. (2010): Sustainable Manufacturing: A Case Study of the Forklift painting Process, in: International Journal of Production Research, Vol. 48, No. 10, pp. 3061-3078.

King, A.A./Lenox, M.J. (2001): Lean and green? An empirical Examination of the Relationship between lean Production and environmental Performance, in: Production and Operations Management, Vol. 10, No. 3, pp. 244-256.

Klein, J./Dawar, N. (2004): Corporate Social Responsibility and Consumers' Attributions and Brand Evaluations in a Product-harm Crisis, in: International Journal of Research in Marketing, Vol. 21, No. 3, pp. 203-217.

Kleindorfer, P.R., et al. (2005): Sustainable Operations Management, in: Production and Operations Management, Vol. 14, No. 4, pp. 482-493.

Koplin, J., et al. (2007): Incorporating Sustainability into Supply Management in the Automotive Industry - the Case of the Volkswagen AG, in: Journal of Cleaner Production, Vol. 15, No. 11-12, pp. 1053-1062.

Kortelainen, K. (2008): Global Supply Chains and social Requirements: Case Studies of Labour Condition Auditing in the People's Republic of China, in: Business Strategy and the Environment, Vol. 17, No. 7, pp. 431-443.

Kovács, G. (2008): Corporate environmental Responsibility in the Supply Chain, in: Journal of Cleaner Production, Vol. 16, No. 15, pp. 1571-1578.

Kraines, S. (2002): Pollution and Cost in the Coke-Making Supply Chain in Shanxi Province, China, in: Journal of Industrial Ecology, Vol. 6, No. 3-4, pp. 161-184. 
Krause, D.R., et al. (2009): Special Topic Forum on sustainable Supply Chain Management: Introduction and Reflections on the Role of Purchasing Management, in: Journal of Supply Chain Management: A Global Review of Purchasing \& Supply, Vol. 45, No. 4, pp. 18-25.

Krippendorff, K. (2004): Content Analysis: An Introduction to its Methodology, Thousand Oaks.

Krueger, D. (2008): The Ethics of Global Supply Chains in China - Convergences of East and West, in: Journal of Business Ethics, Vol. 79, No. 1-2, pp. 113-120.

Lamnek, S. (2005): Qualitative Sozialforschung, Weinheim.

Lee, D., et al. (2010): The Design of sustainable Logistics Network under Uncertainty, in: International Journal of Production Economics, Vol. 128, No. 1, pp. 159-166.

Lélé, S.M. (1991): Sustainable Development: A critical Review, in: World Development, Vol. 19, No. 6, pp. 607-621.

Li, C., et al. (2010): A Methodology for selecting a green Technology Portfolio based on Synergy, in: International Journal of Production Research, Vol. 48, No. 24, pp. 7289-7302.

Li, X., et al. (2009): A strategic Performance Measurement System for Firms across Supply and Demand Chains on the Analogy of Ecological Succession, in: Ecological Economics, Vol. 68, No. 12, pp. 2918-2929.

Lichtenstein, D.R., et al. (2004): The Effect of Corporate Social Responsibility on Customer Donations to Corporate-Supported Nonprofits, in: Journal of Marketing, Vol. 68, No. 4, pp. 16-32.

Lieb, K.J./Lieb, R.C. (2010): Environmental Sustainability in the third-party Logistics (3PL) Industry, in: International Journal of Physical Distribution \& Logistics Management, Vol. 40, No. 7, pp. 524-533.

Linton, J.D., et al. (2007): Sustainable Supply Chains: An Introduction, in: Journal of Operations Management, Vol. 25, No. 6, pp. 1075-1082.

Lockett, A., et al. (2006): Corporate Social Responsibility in Management Research: Focus, Nature, Salience and Sources of Influence, in: Journal of Management Studies, Vol. 43, No. 1, pp. 115-136.

Lu, L.Y.Y., et al. (2007): Environmental principles applicable to green supplier evaluation by using multi-objective decision analysis, in: International Journal of Production Research, Vol. 45, No. 18/19, pp. 4317-4331.

Luchs, M.G., et al. (2010): The Sustainability Liability: Potential negative Effects of Ethicality on Product Preference, in: Journal of Marketing, Vol. 74, No. 5, pp. 18-31.

Luo, X./Bhattacharya, C.B. (2006): Corporate Social Responsibility, Customer Satisfaction, and Market Value, in: Journal of Marketing, Vol. 70, No. 4, pp. 1-18.

Mackey, A., et al. (2007): Corporate Social Responsibility and Firm Performance: Investor Preferences and Corporate Strategies, in: Academy of Management Review, Vol. 32, No. 3, pp. 817-835.

Maignan, I./Ferrell, O.C. (2004): Corporate Social Responsibility and Marketing: An Integrative Framework, in: Journal of the Academy of Marketing Science, Vol. 32, No. 1, pp. 3-19.

Maignan, I./Ralston, D.A. (2002): Corporate Social Responsibility in Europe and the U.S.: Insights from Businesses' Self-presentations, in: Journal of International Business Studies, Vol. 33, No. 3, pp. 497-514.

Maloni, M.J./Brown, M.E. (2006): Corporate Social Responsibility in the Supply Chain: An Application in the Food Industry, in: Journal of Business Ethics, Vol. 68, No. 1, pp. 35-52.

Mamic, I. (2005): Managing Global Supply Chain: The Sports Footwear, Apparel and Retail Sectors, in: Journal of Business Ethics, Vol. 59, No. 1-2, pp. 81-100. 
Markley, M.J./Davis, L. (2007): Exploring future Competitive Advantage through sustainable Supply Chains, in: International Journal of Physical Distribution \& Logistics Management, Vol. 37, No. 9, pp. 763-774.

Matos, S./Hall, J. (2007): Integrating sustainable Development in the Supply Chain: The Case of Life Cycle Assessment in Oil and Gas and agricultural Biotechnology, in: Journal of Operations Management, Vol. 25, No. 6, pp. 1083-1102.

Matten, D./Moon, J. (2008): "Implicit" and "explicit" CSR: A conceptual Framework for a comparative Understanding of Corporate Social Responsibility, in: Academy of Management Review, Vol. 33, No. 2, pp. 404-424.

Mayring, P. (2002): Einführung in die Qualitative Sozialforschung, Weinheim.

Mayring, P. (2003): Qualitative Inhaltsanalyse - Grundlagen und Techniken, Weinheim.

McGuire, J.B., et al. (1988): Corporate Social Responsibility and Firm financial Performance, in: Academy of Management Journal, Vol. 31, No. 4, pp. 854-872.

McWilliams, A./Siegel, D. (2000): Corporate Social Responsibility and financial Performance: Correlation or Misspecification?, in: Strategic Management Journal, Vol. 21, No. 5, pp. 603-610.

McWilliams, A./Siegel, D. (2001): Corporate Social Responsibility: A Theory of the Firm Perspective, in: Academy of Management Review, Vol. 26, No. 1, pp. 117-127.

McWilliams, A., et al. (2006): Corporate Social Responsibility: Strategic Implications, in: Journal of Management Studies, Vol. 43, No. 1, pp. 1-18.

Meisner Rosen, C., et al. (2002): The Role of voluntary Industry Standards in environmental SupplyChain Management, in: Journal of Industrial Ecology, Vol. 6, No. 3-4, pp. 103-123.

Meisner Rosen, C., et al. (2000): Environmental Supply-Chain Management in the Computer Industry: A Transaction Cost Economics Perspective, in: Journal of Industrial Ecology, Vol. 4, No. 4, pp. 83-103.

Melville, N. (2010): Information Systems Innovation for environmental Sustainability, in: MIS Quarterly, Vol. 34, No. 1, pp. 1-21.

Mentzer, J.T. (2008): Rigor versus Relevance: Why would we choose only one?, in: Journal of Supply Chain Mangement, Vol. 44, No. 2, pp. 72-77.

Mentzer, J.T., et al. (2001): Defining Supply Chain Management, in: Journal of Business Logistics, Vol. 22, No. 2, pp. 1-26.

Mintcheva, V. (2005): Indicators for environmental Policy Integration in the Food Supply Chain (The Case of the Tomato Ketchup Supply Chain and the integrated Product Policy), in: Journal of Cleaner Production, Vol. 13, No. 7, pp. 717-731.

Mintzberg, H. (2005): Theory about the Development of Theory in: Smith, K.G./ Hitt, M.A. (Ed.): Great Minds in Management, Oxford, pp. 355-372.

Mollenkopf, D., et al. (2010): Green, lean, and global Supply Chains, in: International Journal of Physical Distribution \& Logistics Management, Vol. 40, No. 1/2, pp. 14-41.

Müller, M., et al. (2009): The Contribution of environmental and social Standards towards Ensuring Legitimacy in Supply Chain Governance, in: Journal of Business Ethics, Vol. 89, No. 4, pp. 509-523.

Murphy, P.R., et al. (1996): Green Logistics: Comparative Views of environmental Progressives, Moderates, and Conservatives, in: Journal of Business Logistics, Vol. 17, No. 1, pp. 191-212.

Nawrocka, D., et al. (2009): ISO 14001 in environmental Supply Chain Practices, in: Journal of Cleaner Production, Vol. 17, No. 16, pp. 1435-1443. 
Newton, T./Harte, G. (1997): Green Business: Technicist Kitsch?, in: Journal of Management Studies, Vol. 34, No. 1, pp. 75-98.

Nijkamp, P. (1994): Roads toward environmentally sustainable Transport, in: Transportation Research Part A: Policy \& Practice, Vol. 28A, No. 4, pp. 261-272.

O Brien, C. (1999): Sustainable Production - A new Paradigm for a new Millennium, in: International Journal of Production Economics, Vol. 60-61, No. pp. 1-6.

Pagell, M./Gobeli, D. (2009): How Plant Managers' Experiences and Attitudes Toward Sustainability Relate to Operational Performance, in: Production and Operations Management, Vol. 18, No. 3, pp. 278-299.

Pagell, M., et al. (2008): Sustainable Supply Chain Management: Theory and Practice, in: Journal of Supply Chain Management: A Global Review of Purchasing \& Supply, Vol. 44, No. 1, pp. 85-85.

Pagell, M./Wu, Z. (2009): Building a more complete Theory of sustainable Supply Chain Management using Case Studies of 10 Exemplars, in: Journal of Supply Chain Management: A Global Review of Purchasing \& Supply, Vol. 45, No. 2, pp. 37-56.

Pagell, M., et al. (2010): Thinking differently about Purchasing Portfolios: An Assessment of sustainable Sourcing, in: Journal of Supply Chain Management: A Global Review of Purchasing \& Supply, Vol. 46, No. 1, pp. 57-73.

Park-Poaps, H./Rees, K. (2010): Stakeholder Forces of Socially Responsible Supply Chain Management Orientation, in: Journal of Business Ethics, Vol. 92, No. 2, pp. 305-322.

Petrini, M./Pozzebon, M. (2009): Managing Sustainability with the Support of Business Intelligence: Integrating socio-environmental Indicators and organisational Context, in: The Journal of Strategic Information Systems, Vol. 18, No. 4, pp. 178-191.

Presley, A., et al. (2007): A strategic Sustainability Justification Methodology for organizational Decisions: A reverse Logistics Illustration, in: International Journal of Production Research, Vol. 45, No. 18/19, pp. 4595-4620.

Preuss, L. (2001): In dirty Chains? Purchasing and greener Manufacturing, in: Journal of Business Ethics, Vol. 34, No. 3/4, pp. 345-359.

Preuss, L. (2005): Rhetoric and Reality of Corporate Greening: A View from the Supply Chain Management Function, in: Business Strategy and the Environment, Vol. 14, No. 2, pp. 123-139.

Prieto-Carrón, M. (2008): Women Workers, Industrialization, Global Supply Chains and Corporate Codes of Conduct, in: Journal of Business Ethics, Vol. 83, No. 1, pp. 5-17.

Pullman, M.E., et al. (2009): Food for Thought: Social versus environmental Sustainability Practices and Performance Outcomes, in: Journal of Supply Chain Management: A Global Review of Purchasing \& Supply, Vol. 45, No. 4, pp. 38-54.

Quak, H.J./De Koster, M.B.M. (2007): Exploring Retailers' Sensitivity to local Sustainability Policies, in: Journal of Operations Management, Vol. 25, No. 6, pp. 1103-1122.

Quariguasi Frota Neto, J., et al. (2008): Designing and evaluating sustainable Logistics Networks, in: International Journal of Production Economics, Vol. 111, No. 2, pp. 195-208.

Quariguasi Frota Neto, J., et al. (2010): From closed-loop to sustainable Supply Chains: The WEEE Case, in: International Journal of Production Research, Vol. 48, No. 15, pp. 4463-4481.

Reiskin, E.D., et al. (1999): Servicizing the chemical Supply Chain, in: Journal of Industrial Ecology, Vol. 3, No. 2-3, pp. 19-31.

Reuter, C., et al. (2010): Sustainable global Supplier Management: The Role of dynamic Capabilities in achieving competitive Advantage, in: Journal of Supply Chain Management, Vol. 46, No. 2, pp. 45-63. 
Roberts, S. (2003): Supply Chain specific? Understanding the patchy Success of ethical Sourcing Initiatives, in: Journal of Business Ethics, Vol. 44, No. 2/3, pp. 159-170.

Robin, D.P./Reidenbach, R.E. (1987): Social Responsibility, Ethics, and Marketing Strategy: Closing the Gap Between Concept and Application, in: Journal of Marketing, Vol. 51, No. 1, pp. 44-58.

Rodriguez, P., et al. (2006): Three Lenses on the multinational Enterprise: Politics, Corruption, and Corporate Social Responsibility, in: Journal of International Business Studies, Vol. 37, No. 6, pp. 733-746.

Roth, A./Kåberger, T. (2002): Making Transport Systems sustainable, in: Journal of Cleaner Production, Vol. 10, No. 4, pp. 361-371.

Rothenberg, S., et al. (2001): Lean, green, and the Quest for superior environmental Performance, in: Production and Operations Management, Vol. 10, No. 3, pp. 228-243.

Russo, M.V. (2003): The Emergence of sustainable Industries: Building on natural Capital, in: Strategic Management Journal, Vol. 24, No. 4, pp. 317-332.

Saint Jean, M. (2008): Polluting Emissions Standards and clean Technology Trajectories under competitive Selection and Supply Chain Pressure, in: Journal of Cleaner Production, Vol. 16, No. 1, Supplement 1, pp. 113-123.

Salam, M. (2009): Corporate Social Responsibility in Purchasing and Supply Chain, in: Journal of Business Ethics, Vol. 85, No. pp. 355-370.

Sanchez-Rodrigues, V., et al. (2010): The Impact of Logistics Uncertainty on sustainable Transport Operations, in: International Journal of Physical Distribution \& Logistics Management, Vol. 40, No. 1/2, pp. 61-83.

Sarkis, J. (2003): A strategic Decision Framework for green Supply Chain Management, in: Journal of Cleaner Production, Vol. 11, No. 4, pp. 397-409.

Scherer, A.G./Palazzo, G. (2007): Toward a political Conception of Corporate Responsibility: Business and Society seen from a Habermasian Perspective, in: Academy of Management Review, Vol. 32, No. 4, pp. 1096-1120.

Schliephake, K., et al. (2009): Making Resources work more efficiently - the Importance of Supply Chain Partnerships, in: Journal of Cleaner Production, Vol. 17, No. 14, pp. 1257-1263.

Schmidt, M./Schwegler, R. (2008): A recursive ecological Indicator System for the Supply Chain of a Company, in: Journal of Cleaner Production, Vol. 16, No. 15, pp. 1658-1664.

Schrader, U./Hennig-Thurau, T. (2009): VHB-JOURQUAL2: Method, Results, and Implications of the German Academic Association for Business Research's Journal Ranking, in: BuR - Business Research, Vol. 2, No. 2, pp. 180-204.

Sen, S./Bhattacharya, C.B. (2001): Does Doing Good Always Lead to Doing Better? Consumer Reactions to Corporate Social Responsibility, in: Journal of Marketing Research (JMR), Vol. 38, No. 2, pp. 225-243.

Sen, S., et al. (2006): The Role of Corporate Social Responsibility in Strengthening Multiple Stakeholder Relationships: A Field Experiment, in: Journal of the Academy of Marketing Science, Vol. 34, No. 2, pp. 158-166.

Seuring, S. (2004a): Industrial Ecology, Life Cycles, Supply Chains: Differences and Interrelations, in: Business Strategy and the Environment, Vol. 13, No. 5, pp. 306-319.

Seuring, S. (2004b): Integrated Chain Management and Supply Chain Management comparative Analysis and illustrative Cases, in: Journal of Cleaner Production, Vol. 12, No. 8-10, pp. 1059-1071. 
Seuring, S. (2009): Greening the Supply Chain - A Guide for Asian Managers, in: Journal of Cleaner Production, Vol. 17, No. 9, pp. 886-886.

Seuring, S./Müller, M. (2008a): Core Issues in sustainable Supply Chain Management - a Delphi Study, in: Business Strategy and the Environment, Vol. 17, No. 8, pp. 455-466.

Seuring, S./Müller, M. (2008b): From a Literature Review to a conceptual Framework for sustainable Supply Chain Management, in: Journal of Cleaner Production, Vol. 16, No. 15, pp. 1699-1710.

Seuring, S., et al. (2008): Sustainability and Supply Chain Management - An Introduction to the special Issue, in: Journal of Cleaner Production, Vol. 16, No. 15, pp. 1545-1551.

Sharfman, M., et al. (2009): The Road to cooperative Supply-Chain environmental Management: Trust and Uncertainty among pro-active Firms, in: Business Strategy and the Environment, Vol. 18, No. 1, pp. 1-13.

Sharma, S. (2002): Sustainability: What really matters?, in: Sharma, S./ Starik, M. (Ed.): Research in Corporate Sustainability, Cheltenham, pp. 1-29.

Sharma, S./Henriques, I. (2005): Stakeholder Influences on Sustainability Practices in the Canadian Forest Products Industry, in: Strategic Management Journal, Vol. 26, No. 2, pp. 159-180.

Sheu, J.-B. (2008): Green Supply Chain Management, reverse Logistics and nuclear Power Generation, in: Transportation Research: Part E, Vol. 44, No. 1, pp. 19-46.

Sheu, J.-B., et al. (2005): An integrated Logistics operational Model for Green-supply Chain Management, in: Transportation Research: Part E, Vol. 41, No. 4, pp. 287-313.

Shrivastava, P. (1995): The Role of Corporations in achieving ecological Sustainability, in: The Academy of Management Review, Vol. 20, No. 4, pp. 936-961.

Shuili, D., et al. (2007): Reaping relational Rewards from Corporate Social Responsibility: The Role of competitive Positioning, in: International Journal of Research in Marketing, Vol. 24, No. 3, pp. 224-241.

Siegel, D.S./Vitaliano, D.F. (2007): An empirical Analysis of the strategic Use of Corporate Social Responsibility, in: Journal of Economics \& Management Strategy, Vol. 16, No. 3, pp. 773-792.

Sigala, M. (2008): A Supply Chain Management Approach for investigating the Role of Tour Operators on sustainable Tourism: The Case of TUI, in: Journal of Cleaner Production, Vol. 16, No. 15, pp. 1589-1599.

Singhapakdi, A., et al. (1995): The Perceived Importance of Ethics and Social Responsibility on Organizational Effectiveness: A Survey of Marketers, in: Journal of the Academy of Marketing Science, Vol. 23, No. 1, pp. 49-56.

Smith, N.C. (2009): Bounded Goodness: Marketing Implications of Drucker on Corporate Responsibility, in: Journal of the Academy of Marketing Science, Vol. 37, No. 1, pp. 73-84.

Smith, N.C., et al. (2010): Marketing's Consequences: Stakeholder Marketing and Supply Chain Corporate Social Responsibility Issues, in: Business Ethics Quarterly, Vol. 20, No. 4, pp. 617-641.

Sobczak, A. (2006): Are Codes of Conduct in global Supply Chains really voluntary? From soft Law Regulation of Labour Relations to Consumer Law, in: Business Ethics Quarterly, Vol. 16, No. 2, pp. 167-184.

Solér, C., et al. (2010): Green Supply Chains and the missing Link between environmental Information and Practice, in: Business Strategy and the Environment, Vol. 19, No. 1, pp. 14-25.

Sonesson, U./Berlin, J. (2003): Environmental Impact of future Milk Supply Chains in Sweden: A Scenario Study, in: Journal of Cleaner Production, Vol. 11, No. 3, pp. 253-266.

Srivastava, S.K. (2007): Green Supply-Chain Management: A state-of-the-art Literature Review, in: International Journal of Management Reviews, Vol. 9, No. 1, pp. 53-80. 
Starik, M./Rands, G.P. (1995): Weaving an integrated Web: Multilevel and multisystem Perspectives of ecologically sustainable Organizations, in: Academy of Management. The Academy of Management Review, Vol. 20, No. 4, pp. 908-936.

Starkey, K./Crane, A. (2003): Toward green Narrative: Management and the Evolutionary Epic, in: Academy of Management Review, Vol. 28, No. 2, pp. 220-237.

Stock, J.R./Boyer, S.L. (2009): Developing a consensus Definition of Supply Chain Management: A qualitative Study, in: International Journal of Physical Distribution \& Logistics Management, Vol. 39, No. 8, pp. 690-711.

Strand, R. (2009): Corporate Responsibility in Scandinavian Supply Chains, in: Journal of Business Ethics, Vol. 85, No. pp. 179-185.

Strike, V.M., et al. (2006): Being good while being bad: Social Responsibility and the International Diversification of US firms, in: Journal of International Business Studies, Vol. 37, No. 6, pp. 850-862.

Surroca, J., et al. (2010): Corporate Responsibility and Financial Performance: The Role of Intangible Resources, in: Strategic Management Journal, Vol. 31, No. 5, pp. 463-490.

Tan, R.B.H./Khoo, H.H. (2005): An LCA Study of a primary Aluminum Supply Chain, in: Journal of Cleaner Production, Vol. 13, No. 6, pp. 607-618.

Tate, W.L., et al. (2010): Corporate Social Responsibility Reports: A thematic Analysis related to Supply Chain Management, in: Journal of Supply Chain Management: A Global Review of Purchasing \& Supply, Vol. 46, No. 1, pp. 19-44.

Taylor, J. (1994): The Challenge of sustainable Development, in: Regulation, Vol. 17, No. 1, pp. 35-51.

Thun, J./Müller, A. (2010): An empirical Analysis of green Supply Chain Management in the German Automotive Industry, in: Business Strategy and the Environment, Vol. 19, No. 2, pp. 119-132.

Toolsema, L.A. (2009): Interfirm and intrafirm Switching Costs in a vertical Differentiation Setting: Green versus nongreen Products, in: Journal of Economics \& Management Strategy, Vol. 18, No. 1, pp. 263-284.

Tsai, W./Hung, S. (2009): A fuzzy Goal Programming Approach for green Supply Chain Optimisation under Activity-based Costing and Performance Evaluation with a Value-Chain Structure, in: International Journal of Production Research, Vol. 47, No. 18, pp. 4991-5017.

Tsoulfas, G.T./Pappis, C.P. (2006): Environmental Principles applicable to Supply Chains Design and Operation, in: Journal of Cleaner Production, Vol. 14, No. 18, pp. 1593-1602.

Tsoulfas, G.T./Pappis, C.P. (2008): A Model for Supply Chains environmental Performance Analysis and Decision Making, in: Journal of Cleaner Production, Vol. 16, No. 15, pp. 1647-1657.

Vachon, S. (2007): Green Supply Chain Practices and the Selection of environmental Technologies, in: International Journal of Production Research, Vol. 45, No. 18/19, pp. 4357-4379.

Vachon, S./Klassen, R.D. (2006): Green Project Partnership in the Supply Chain: The Case of the Package Printing Industry, in: Journal of Cleaner Production, Vol. 14, No. 6-7, pp. 661-671.

Vachon, S./Mao, Z. (2008): Linking Supply Chain Strength to sustainable Development: A countrylevel Analysis, in: Journal of Cleaner Production, Vol. 16, No. 15, pp. 1552-1560.

van der Vorst, J., et al. (2009): Simulation Modelling for Food Supply Chain Redesign; integrated Decision making on Product Quality, Sustainability and Logistics, in: International Journal of Production Research, Vol. 47, No. 23, pp. 6611-6631.

van Hoek, R./Johnson, M. (2010): Sustainability and Energy Efficiency, in: International Journal of Physical Distribution \& Logistics Management, Vol. 40, No. 1/2, pp. 148-158. 
van Tulder, R., et al. (2009): From Chain Liability to Chain Responsibility: MNE Approaches to implement Safety and Health Codes in International Supply Chains, in: Journal of Business Ethics, Vol. 85, No. pp. 399-412.

Vlachos, P.A., et al. (2009): Corporate Social Responsibility: Attributions, Loyalty, and the mediating Role of Trust, in: Journal of the Academy of Marketing Science, Vol. 37, No. 2, pp. 170-180.

vom Brocke, J., et al. (2009): Reconstructing the Giant: On the Importance of Rigour in documenting the Literature Search Process, pp. 1-14.

Vurro, C., et al. (2009): Shaping Sustainable Value Chains: Network Determinants of Supply Chain Governance Models, in: Journal of Business Ethics, Vol. 90, No. pp. 607-621.

Waddock, S. (2009): Making a Difference? Corporate Responsibility as a social Movement, in: Journal of Corporate Citizenship, Vol. No. 33, pp. 35-46.

Wagner, T., et al. (2009): Corporate Hypocrisy: Overcoming the Threat of Inconsistent Corporate Social Responsibility Perceptions, in: Journal of Marketing, Vol. 73, No. 6, pp. 77-91.

Waldman, D.A., et al. (2006a): Cultural and Leadership Predictors of Corporate Social Responsibility Values of Top Management: A Globe Study of 15 Countries, in: Journal of International Business Studies, Vol. 37, No. 6, pp. 823-837.

Waldman, D.A., et al. (2006b): Components of CEO transformational Leadership and Corporate Social Responsibility, in: Journal of Management Studies, Vol. 43, No. 8, pp. 1703-1725.

Walton, S.V., et al. (1998): The green Supply Chain: Integrating Suppliers into environmental Management Processes, in: International Journal of Purchasing and Materials Management, Vol. 34, No. 2, pp. 2-12.

Watson, R., et al. (2010a): Information Systems and environmentally sustainable Development: Energy Informatics and new Directions for the IS Community, in: MIS Quarterly, Vol. 34, No. 1, pp. 23-38.

Watson, R.T., et al. (2010b): Green Projects: An Information Drives Analysis of four Cases, in: The Journal of Strategic Information Systems, Vol. 20, No. 1, pp. 55-62.

WCED (1987): Our Common Future, Oxford.

Webster, J./Watson, R.T. (2002): Analyzing the Past to prepare for the Future: Writing a Literature Review, in: MIS Quarterly, Vol. 26, No. 2, pp. 13-23.

Wee, H./Chung, C. (2009): Optimising replenishment Policy for an integrated Production Inventory deteriorating Model considering green Component-Value Design and Remanufacturing, in: International Journal of Production Research, Vol. 47, No. 5, pp. 1343-1368.

Whatling, D.R., et al. (2010): Corporate Responsibility Reporting of Biodiversity in the Supply Chain, in: International Journal of Innovation and Sustainable Development, Vol. Volume 5, No. 1, pp. 51-64.

Wilson, M. (2003): Corporate Sustainability: What is it and where does it come from?, in: Ivey Business Journal, Vol. 67, No. 6, pp. 1-6.

Windsor, D. (2006): Corporate Social Responsibility: Three Key Approaches, in: Journal of Management Studies, Vol. 43, No. 1, pp. 93-114.

Wu, H.-J./Dunn, S.C. (1995): Environmentally responsible Logistics Systems, in: International Journal of Physical Distribution \& Logistics Management, Vol. 25, No. 2, pp. 20-39.

Wycherley, I. (1999): Greening Supply Chains: The Case of the Body Shop International, in: Business Strategy and the Environment, Vol. 8, No. 2, pp. 120-127.

Yadong, L. (2006): Political Behavior, Social Responsibility and perceived Corruption: A Structuration Perspective, in: Journal of International Business Studies, Vol. 37, No. 6, pp. 747-766. 
Yedla, S./Shrestha, R.M. (2003): Multi-criteria Approach for the Selection of alternative Options for environmentally sustainable Transport System in Delhi, in: Transportation Research Part A: Policy \& Practice, Vol. 37, No. 8, pp. 717-730.

Yin, R.K. (2003): Case Study Research, Thousand Oaks.

Young, R.R. (2000): Managing residual Disposition: Achieving Economy, environmental Responsibility, and competitive Advantage using the Supply Chain Framework, in: Journal of Supply Chain Management: A Global Review of Purchasing \& Supply, Vol. 36, No. 1, pp. 57-66.

Zhu, Q. (2008): Green Supply Chain Management Implications for Closing the Loop, in: Transportation Research: Part E, Vol. 44, No. 1, pp. 1-18.

Zhu, Q./Cote, R.P. (2004): Integrating green Supply Chain Management into an embryonic eco-industrial Development: A Case Study of the Guitang Group, in: Journal of Cleaner Production, Vol. 12, No. 8-10, pp. 1025-1035.

Zhu, Q./Sarkis, J. (2004): Relationships between operational Practices and Performance among early Adopters of green Supply Chain Management practices in Chinese Manufacturing Enterprises, in: Journal of Operations Management, Vol. 22, No. 3, pp. 265-289.

Zhu, Q./Sarkis, J. (2006): An inter-sectoral Comparison of green Supply Chain Management in China: Drivers and Practices, in: Journal of Cleaner Production, Vol. 14, No. 5, pp. 472-486.

Zhu, Q./Sarkis, J. (2007): The moderating Effects of institutional Pressures on emergent green Supply Chain Practices and Performance, in: International Journal of Production Research, Vol. 45, No. 18/19, pp. 4333-4355.

Zhu, Q., et al. (2007): Green Supply Chain Management: Pressures, Practices and Performance within the Chinese Automobile Industry, in: Journal of Cleaner Production, Vol. 15, No. 11-12, pp. 1041-1052.

Zhu, Q., et al. (2008): Confirmation of a Measurement Model for green Supply Chain Management Practices Implementation, in: International Journal of Production Economics, Vol. 111, No. 2, pp. 261-273.

Zikmund, W.G. (2003): Business Research Methods, Ohio.

Nicole Kudla, Dipl.-Logist., ist wissenschaftliche Mitarbeiterin am Lehrstuhl für Logistikmanagement der Universität St.Gallen.

Wolfgang Stölzle, Prof. Dr., leitet an der Universität St.Gallen den Lehrstuhl für Logistikmanagement und als Studiendirektor das berufsbegleitende Diplomstudium Logistikmanagement.

Anschrift: Universität St.Gallen, Lehrstuhl für Logistikmanagement, Dufourstr. 40a, CH-9000 St. Gallen, Tel. +41 (0)71/224-7280, Fax: +41 (0)71/224-7315; Email: nicole.kudla@unisg.ch / wolfgang.stoelzle@unisg.ch 